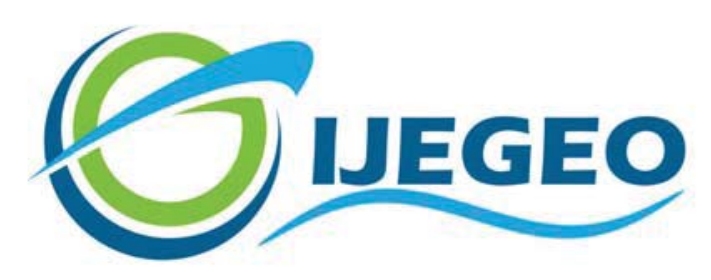

International Journal of Environment and Geoinformatics (IJEGEO) is an international, multidisciplinary, peer reviewed, open access journal.

\title{
The Effects of Atmospheric Oscillations on Crop (Olive, Grape and Cotton) Yield in the Eastern Part of the Mediterranean Region, Turkey
}

\section{Aslı UZUN, Beyza USTAOĞLU}

\author{
Chief in Editor \\ Prof. Dr. Cem Gazioğlu \\ Co-Editors Prof. Dr. Dursun Zafer Şeker, Prof. Dr. Şinasi Kaya, \\ Prof. Dr. Ayşegül Tanık and Assist. Prof. Dr. Volkan Demir
}

Editorial Committee (March 2022)

Assoc. Prof. Dr. Abdullah Aksu (TR), Assoc. Prof. Dr. Uğur Algancı (TR), Assoc. Prof. Dr. Aslı Aslan (US), Prof. Dr. Levent Bat (TR), Prof. Dr. Paul Bates (UK), İrşad Bayırhan (TR), Prof. Dr. Bülent

Bayram (TR), Prof. Dr. Luis M. Botana (ES), Prof. Dr. Nuray Çağlar (TR), Prof. Dr. Sukanta Dash (IN), Dr. Soofia T. Elias (UK), Prof. Dr. A. Evren Erginal (TR), Assoc. Prof. Dr. Cüneyt Erenoğlu (TR), Dr. Dieter Fritsch (DE), Prof. Dr. Ç; Prof. Dr. Manik Kalubarme (IN), Dr. Hakan Kaya (TR), Assist. Prof. Dr. Serkan Kükrer (TR), Assoc. Prof. Dr. Maged Marghany (MY); Prof. Dr. Micheal Meadows (ZA), Prof. Dr. Nebiye Musaoğlu (TR), Prof. Dr. Masafumi Nakagawa (JP), Prof. Dr. Hasan Özdemir (TR), Prof. Dr. Chyssy Potsiou (GR), Prof. Dr. Erol Sarı (TR), Prof. Dr. Maria Paradiso (IT), Prof. Dr. Petros Patias (GR), Prof. Dr. Elif Sertel (TR), Prof. Dr. Nüket Sivri (TR), Prof. Dr. Füsun

Balık Şanlı (TR), Dr. Duygu Ülker (TR), Prof. Dr. Seyfettin Tsaş (TR), Assoc. Prof. Dr. Ömer Suat Taşkın (TR), Assist. Prof. Dr. Tuba Ünsal (TR), Assist. Prof. Dr. Sibel Zeki (TR) 


\title{
Research Article
}

\section{The Effects of Atmospheric Oscillations on Crop (Olive, Grape and Cotton) Yield in the Eastern Part of the Mediterranean Region, Turkey}

\author{
Aslı Uzun ${ }^{1}$ iD Beyza Ustaoğlu ${ }^{2 *}$ iD \\ ${ }^{1}$ Çankırı Karatekin University, Institute of Social Sciences, Geography Department, Çankırı, Turkey \\ ${ }^{2}$ Sakarya University, Department of Geography,54100, Serdivan-Sakarya, Turkey \\ * Corresponding author: Assoc.Prof.Dr.Beyza Ustaoğlu \\ Received 15.10.2021 \\ E-mail: bustaoglu@sakarya.edu.tr \\ Accepted 11.11.202 \\ How to cite: Uzun and Ustaoğlu (2021). The Effects of Atmospheric Oscillations on Crop (Olive, Grape and Cotton) Yield in the Eastern Part \\ of the Mediterranean Region, Turkey, International Journal of Environment and Geoinformatics (IJEGEO), 9(1):147-161, doi. 10.30897/ijegeo. \\ 1010181
}

\begin{abstract}
In the last century climate change has been a major threat to biodiversity, ecosystem services, and human wellbeing. Atmospheric oscillations that occur at the regional oceanic flow pattern may affect significantly the climate of the Earth. In this study, we investigate the effects of ENSO (El Nino Southern Oscillation) and NAO (North Atlantic Oscillation) on the Mediterranean crop yield using the Nino 3, Nino3.4, Nino 4, ONI and NAO indices. Olive, which is a bioindicator type in the Mediterranean, and cotton and grapes with high yield and economic value crops were examined. According to the average production amounts in the Mediterranean Region between 1991 and 2020, 39\% of cotton production is in Adana (205319 tone), $43 \%$ of grape production is in Mersin (228471 tone) and $37 \%$ of olive production is in Hatay (103854 tone). As a method, firstly, Mann Kendall rank correlation test was applied to the yield values of the crops. After the 2000s, it has been determined that the trend of yield has changed and was obtained an increasing trend. Secondly, the correlation between the yields and Nino 3, Nino3.4, Nino 4, and NAO indices were determined with the Spearman correlation coefficient. Accordingly, a high correlation of $50 \%$ and $80 \%$ was found at the $\mathrm{p} \leq 0.05$ and $\mathrm{p} \leq 0.00$ significance level in the phenological periods of the crops. The highest correlations were determined especially during the flowering period (April, May, June) for olive and grape yield with El Nino indices. The frequency of the correlation detected with the NAO index is weak. The effect on the efficiency of the phases when El Nino indices are strong was examined graphically. Accordingly, in the 1997 and 2015-2016 periods, when the El Nino phenomen was very strong, there were sharp decreases in the crop yields. This variability affects the countries whose economic activity is based on agriculture in the Mediterranean Basin, and it is likely to affect the food industry in the future.
\end{abstract}

Keywords: Climate Change, Atmospheric Oscillations, Mediterranean Region, Crop Yield

\section{Introduction}

Climate is one of the important physical geography factors affecting the distribution and development of plants on the Earth. Climate change causes global and regional environmental problems such as drought, land degradation and desertification, reduction and destruction of biodiversity and forests. If the carbon dioxide level is not fixed at a certain rate and countries do not develop adaptation strategies to climate change impacts, it will cause food and water problems (food and water security, availability, access, consumption and sustainability of food and water), climate migration in the future (Ustaoğlu and İkiel 2007; Stone et al. 2013; Lobell D 2014; Ustaoğlu and Karaca 2014; Gazioğlu 2018, Ülker et al. 2018; Gorji et al. 2019; IPCC, 2021; Malhi et al. 2021; Ortiz-Bobea et al. 2021). It is thought that the increase in the frequency of extreme weather events that have occurred frequently in recent years is related to the changes in large-scale pressure and wind circulation and atmospheric oscillations (Karabörk and Kahya, 2003; Türkeş and Erlat, 2003; Hatzaki et al., 2009; Andrade et al. 2011; Baltac1 et al.2018). It is predicted that the increasing average temperatures in 2015 and the following years may increase the frequency of extreme climatic events and the tendency of the climate to deviate from the long-term average in Turkey and its surroundings (Ustaoğlu, 2018).

El Nino Southern Oscillation is one of the causes of climate variability on a global scale. The Southern Oscillation is defined as the instabilities of atmospheric pressure at sea level between the pacific subtropical high pressure and the low-pressure center along the Indian Ocean (Rasmusson and Wallace, 1983). El Nino Southern Oscillation has an impact on climatic conditions in various parts of the world (Nazemosadat and Cordery 2000; Hasanean 2004; Vázquez et al. 2005; Vicente Serrano 2005; Brönniman et al., 2007; Zuhairi et al. 2013; King et al. 2020; Valdez- Cepeda et al., 2020) affects the weather patterns of countries in the Mediterranean Basin (Price et al., 1998, Nazemosadat and Cordery 2000, Salameh et al., 2019) and also Turkey (Türkeş 1998; Karaca et al.2000; Türkeş, 2000; Karabörk and Kahya 2003; Karabörk et al.2005; Martı 2007; Martı and Kahya 2007; Martı 2014; Tosunoğlu et al.2018, Efe et al., 2019). It was stated that winter precipitation in Turkey showed a significant increase in the previous years after El Nino and La Nina events, a weak trend in the following years after El Nino events, 
and a significant decrease in the following years after La Nina events (Türkeş, 2000). It has been mentioned that the decrease of rainfall in Turkey during the winter months can significantly affect the drought, and generally there is an increase in the northwestern where the rainfall decreases in the southwest of Turkey during the El Nino years (Kadıoglu et al., 1999).

"The North Atlantic Oscillation (NAO) consists of opposing variations of barometric pressure in the subpolar and subtropical regions of the North Atlantic. Generally, there is a high-pressure system in the subtropical zone near the Azores and a low pressure condition near Iceland's subpolar zone. The strength of the pressure gradient between two pressure centers changes over time in the strong and weak phases. The measure of this variation is the NAO indice" (Bachmann, 2007). While the average annual precipitation in winter, spring, autumn, and partly summer in Turkey is mainly defined by longer-term rainy conditions in the negative phase of the NAO, the atmospheric circulation affecting the North Atlantic and Europe in the positive phase of the NAO are drier than the long-term average in Turkey conditions have occurred (Türkeş and Erlat, 2003). Many studies are examining the effect of NAO on climate conditions in Turkey (Baltac1 et al., 2018). This effect of atmospheric oscillations on climate is also observed directly on crops (Gimeno et al., 2002; Zubair 2002; Fraisse et al. 2008; Soler et al. 2010; Bannayan et al., 2011; Rao et al., 2011; Abdolrahimi, 2016; Capa. -Morocho et al, 2014; Iizumi et al, 2014; Gutierrez, 2017; Rojas et al, 2019; Uzun and Ustaoğlu, 2019; Qian et al, 2020; Abahous et al, 2021).

Olive (Olea europaea L.) is a member of the maquis community included in the vegetation of the Mediterranean Climate. Olive is considered a bioindicator that characterizes this zone because of its perfect adaptation to the Mediterranean climate zone (Efe et al., 2009). 90\% of the olives in the world are produced in the Mediterranean Basin and 10\% in Latin American countries (Ministry of Customs and Trade, General Directorate of Cooperatives, 2018a). Between 1991 and 2020, Spain ranks first in olive production globally, Italy is in the second, Morocco is in third place, and Turkey is in fourth place (URL 1) (Table 1). Cotton is of great importance for society, the employment it provides, the economic value it creates, and the producers with its ordinary and necessary areas of use. Due to growing conditions, $80 \%$ of world cotton production is made by a few number of countries, including Turkey (Ministry of Customs and Trade, General Directorate of Cooperatives, 2018b). Between 1991 and 2020, China ranked first in cotton production, India ranked second, and the USA ranked third in world cotton production. Turkey ranks 7th (URL 1) (Table 1). Grape is one of the fruit types with a wide production area in the world. Grape is a perennial garden plant resistant to high and low temperatures, although it is a hot-temperate climate plant (Kaymaz, 2005). Between the years 1991-2020, China ranks first in grape production, Italy ranks second, and the USA ranks third. Turkey ranks 6th in production (URL 1) (Table 1).
Turkey is the largest exporter of seedless raisins globally, with 40-45\% (Ministry of Customs and Trade, General Directorate of Cooperatives, 2018c) (Table 1).

The Mediterranean Region is one of the important agricultural production areas for Turkey. The yield changes occurring in the region affect food industry. Determining the effect of periodically repeated oscillations on variability in efficiency will provide the prevent economic loss. Therefore, in this study, olives, cotton, and grapes, which have high economic value in the Mediterranean Region and can be easily affected by the variations in climatic conditions, have been examined. The relationship between the yield of these crops and atmospheric oscillations has been determined assuming other ecological parameters are constant.

Table 1. Cotton, Grape, Olive production worldwide (1991-2019)

\begin{tabular}{|c|c|c|c|c|c|}
\hline Crop & $\begin{array}{l}\text { Ra } \\
\text { nk }\end{array}$ & Country & $\begin{array}{l}\text { Area } \\
\text { Harves } \\
\text { ted } \\
\text { (ha) } \\
\end{array}$ & $\begin{array}{l}\text { Product } \\
\text { ion } \\
\text { (ton) }\end{array}$ & $\begin{array}{l}\text { Yiel } \\
\mathrm{d} \\
\text { (hg/h } \\
\text { a) } \\
\end{array}$ \\
\hline \multirow{4}{*}{$\begin{array}{l}\text { Oliv } \\
\mathrm{e}\end{array}$} & 1 & Spain & $\begin{array}{l}23664 \\
46\end{array}$ & $\begin{array}{l}541126 \\
6\end{array}$ & $\begin{array}{l}2286 \\
7\end{array}$ \\
\hline & 2 & Italy & $\begin{array}{l}11459 \\
05\end{array}$ & $\begin{array}{l}301471 \\
9\end{array}$ & $\begin{array}{l}2630 \\
9\end{array}$ \\
\hline & 3 & Morocco & $\begin{array}{l}65948 \\
6\end{array}$ & $\begin{array}{l}869716 \\
.1\end{array}$ & $\begin{array}{l}1318 \\
8\end{array}$ \\
\hline & 4 & Turkey & $\begin{array}{l}69961 \\
7 \\
\end{array}$ & $\begin{array}{l}133955 \\
1\end{array}$ & $\begin{array}{l}1914 \\
7\end{array}$ \\
\hline \multirow{4}{*}{$\begin{array}{l}\text { Cott } \\
\text { on }\end{array}$} & 1 & China & $\begin{array}{l}48743 \\
36\end{array}$ & $\begin{array}{l}168113 \\
34\end{array}$ & $\begin{array}{l}3448 \\
9\end{array}$ \\
\hline & 2 & India & $\begin{array}{l}99221 \\
40\end{array}$ & 111617 & $\begin{array}{l}1124 \\
9\end{array}$ \\
\hline & 3 & $\begin{array}{l}\text { United States of } \\
\text { America }\end{array}$ & $\begin{array}{l}46042 \\
67\end{array}$ & $\begin{array}{l}100062 \\
78\end{array}$ & $\begin{array}{l}2173 \\
3\end{array}$ \\
\hline & 7 & Turkey & $\begin{array}{l}57854 \\
1\end{array}$ & $\begin{array}{l}215840 \\
7\end{array}$ & $\begin{array}{l}3730 \\
8\end{array}$ \\
\hline \multirow{4}{*}{$\begin{array}{l}\text { Grap } \\
\mathrm{e}\end{array}$} & 1 & China & $\begin{array}{l}42318 \\
1\end{array}$ & $\begin{array}{l}655799 \\
7\end{array}$ & $\begin{array}{l}1549 \\
69\end{array}$ \\
\hline & 2 & Italy & $\begin{array}{l}80585 \\
1\end{array}$ & $\begin{array}{l}835207 \\
4\end{array}$ & $\begin{array}{l}1036 \\
43\end{array}$ \\
\hline & 3 & $\begin{array}{l}\text { United States of } \\
\text { America }\end{array}$ & $\begin{array}{l}37003 \\
3\end{array}$ & $\begin{array}{l}627719 \\
9\end{array}$ & $\begin{array}{l}1696 \\
39\end{array}$ \\
\hline & 6 & Turkey & $\begin{array}{l}50494 \\
3\end{array}$ & $\begin{array}{l}379660 \\
1\end{array}$ & $\begin{array}{l}7518 \\
9\end{array}$ \\
\hline
\end{tabular}

\section{The Features of Study Area}

The Mediterranean climate is effective in this study area on the southern coastline of Turkey, but the climate does not show the same characteristics everywhere due to the influence of topography (Fig. 1). In parts up to $1000 \mathrm{~m}$, there is the Mediterranean climate, where the summers are hot, and dry winters are warm and rainy, and the parts above $1000 \mathrm{~m}$ are the Mediterranean Mountain climate, where the summers are cool and less rainy, and the winters are cold and snowy (Atalay and Mortan, 2011). According to the Köppen-Geiger climate classification, Csa, a very hot and dry Mediterranean climate with warm summer in the region, is effective. In the northern parts, $B S k$, a semi-arid steppe climate in places, and $D s b$, which has severe winter, dry summer, and cool, are effective (Baylan and Ustaoğlu, 2020). 


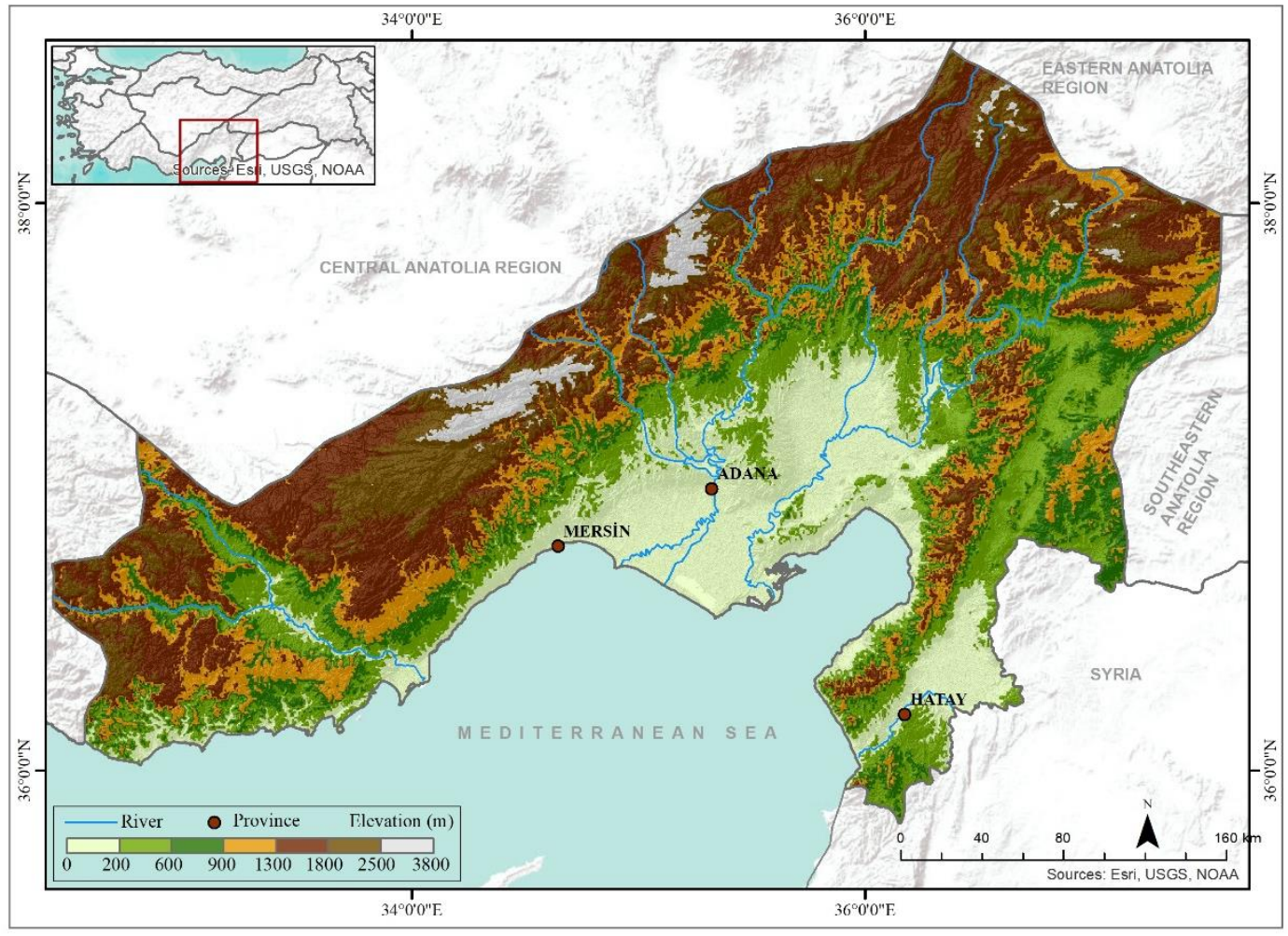

Fig. 1. Geographical Location Map of the Study Area in Eastern Part of the Mediterranean Region

\section{Materials and Methods Materials}

Several indices (such as Nino 3, Nino 3.4, Nino 4) are used to define the tropical Pacific, each based on average SST anomalies in a particular region. Usually, anomalies are calculated against a 30 -year baseline period. The Niño 3.4 index and the Oceanic Niño index (ONI) are the most used indices to describe El Niño and La Niña events. ONI uses the same region as the Niño 3.4 index and includes the quarterly average (Shabbar 2006; Climate Data Guide, 2018; Bertrand et al. 2020). For the study, the ONI was used to determine Nino3, Nino 3.4, Nino 4, and El Nino years taken from NOAA (NOAA, 2021a). Values of +0.5 and above, which are repeated for at least five consecutive periods in the indice, define the year of El Nino, and values of -0.5 and below define the year of La Nina. In addition, years with values between 0.5 and 0.9 are classified as weak, years with values between 1 and 1.4 as a medium, years with values between 1.5 and 1.9 as strong, and years with $\geq 2$ values are classified as very strong (Subash and Gangwar, 2014; Golden Gate Weather Services, 2021). In this study, El Nino and La Nina years were taken from (Subash and Gangwar, 2014), and the other years were determined by examining the ONI according to the criteria mentioned above (Table 2). In this study, the areas with the highest yields were used for each crop. Yield data analyzed to Hatay city for olives, Adana city for cotton, and Mersin city for grapes. Olive is the plant of the Mediterranean basin, where the summers are hot and dry, and the winters are warm and rainy. It is grown in areas where the annual average temperature is $15-20$ ${ }^{0} \mathrm{C}$ (Zengin and Özbahçe, 2014). It can withstand temperatures of up to $35-40{ }^{\circ} \mathrm{C}$. Temperatures should not fall below $-8 /-10{ }^{0} \mathrm{C}$ for olive cultivation. Precipitation is one of the important factors affecting olive yield. The low amount of precipitation causes the fruits to be thin and the yield to decrease. Total annual precipitation for olive cultivation should be between $600-1000 \mathrm{~mm}$ and the winter season should be rainy, the spring and summer seasons should be relatively rainy, and the autumn should be dry (Doğanay and Coşkun, 2012). Also due to the periodicity, while the amount of olive production is higher for one year, it decreases the following year..This situation causes fluctuations in yield values (Efe et al., 2013). Between 1991 and 2020, Mediterranean Region (21\%) ranks 3rd in olive production in Turkey. $37 \%$ of olive production in the Mediterranean region is grown in Hatay (TUIK,2017; 2021) (Table 3). Cotton grows on alluvial soils in warm climatic zones. It needs plenty of water during the phenological period and hot and dry weather conditions during the ripening period (Karabağ and Şahin, 2020). Cotton, which is sensitive to variations in climatic parameters, is affected by frost events during the phenological period (Kara, 1988; Zengin and Özbahçe, 2014). It can be grown without irrigation in areas where the total annual precipitation is $500-700 \mathrm{~mm}$. It needs at least $400-600 \mathrm{~mm}$ of water during the growing season. Autumn and winter precipitation is important because it meets the moisture needed by the plant during the growing period (Doğanay and Coşkun, 2012). Due to these characteristics, Çukurova (Adana) is among the most suitable areas for cotton cultivation in Turkey (Karabağ and Şahin, 2020). Between 1991 and 2020, Mediterranean Region (25\%) ranks 3rd in cotton production in Turkey. 39\% of cotton production in the Mediterranean region is grown in Adana (TUIK,2017; TUIK 2021) (Table 4). 
Uzun and Ustaoğlu / IJEGEO 9(1): 147-161 (2022)

Table 2. Oceanic Nino Index (ONI) (Source: NOAA, 2021b)

\begin{tabular}{|c|c|c|c|c|c|c|c|c|c|c|c|c|}
\hline Year & DJF & JFM & FMA & MAM & AMJ & MJJ & JJA & JAS & ASO & SON & OND & NDJ \\
\hline 1991 & 0,4 & 0,3 & 0,2 & 0,3 & 0,5 & 0,6 & 0,7 & 0,6 & 0,6 & 0,8 & 1,2 & 1,5 \\
\hline 1992 & 1,7 & 1,6 & 1,5 & 1,3 & 1,1 & 0,7 & 0,4 & 0,1 & $-0,1$ & $-0,2$ & $-0,3$ & $-0,1$ \\
\hline 1993 & 0,1 & 0,3 & 0,5 & 0,7 & 0,7 & 0,6 & 0,3 & 0,3 & 0,2 & 0,1 & 0 & 0,1 \\
\hline 1994 & 0,1 & 0,1 & 0,2 & 0,3 & 0,4 & 0,4 & 0,4 & 0,4 & 0,6 & 0,7 & 1 & 1,1 \\
\hline 1995 & 1 & 0,7 & 0,5 & 0,3 & 0,1 & 0 & $-0,2$ & $-0,5$ & $\begin{array}{l}-0,8 \\
\end{array}$ & -1 & -1 & -1 \\
\hline 1996 & $-0,9$ & $-0,8$ & $-0,6$ & $-0,4$ & $-0,3$ & $-0,3$ & $-0,3$ & $-0,3$ & $-0,4$ & $-0,4$ & $-0,4$ & $-0,5$ \\
\hline 1997 & $-0,5$ & $-0,4$ & $-0,1$ & 0,3 & 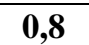 & 1,2 & 1,6 & 1,9 & 2,1 & 2,3 & 2,4 & 2,4 \\
\hline 1998 & 2,2 & 1,9 & 1,4 & 1 & 0,5 & $-0,1$ & $-0,8$ & $-1,1$ & \begin{tabular}{|c|}
$-1,3$ \\
\end{tabular} & $-1,4$ & $-1,5$ & $-1,6$ \\
\hline 1999 & $-1,5$ & $-1,3$ & $-1,1$ & -1 & -1 & -1 & $-1,1$ & $-1,1$ & $-1,2$ & $-1,3$ & $-1,5$ & $-1,7$ \\
\hline 2000 & $\begin{array}{l}-1,7 \\
\end{array}$ & $-1,4$ & $-1,1$ & $\begin{array}{l}-0,8 \\
\end{array}$ & $\begin{array}{l}-0,7 \\
\end{array}$ & $\begin{array}{l}-0,6 \\
\end{array}$ & $-0,6$ & $-0,5$ & $\begin{array}{l}-0,5 \\
\end{array}$ & $-0,6$ & $\begin{array}{c}-0,7 \\
\end{array}$ & $-0,7$ \\
\hline 2001 & $\begin{array}{c}-0,7 \\
\end{array}$ & $-0,5$ & $-0,4$ & $-0,3$ & $\begin{array}{l}-0,3 \\
\end{array}$ & $-0,1$ & $-0,1$ & $\begin{array}{l}-0,1 \\
\end{array}$ & $-0,2$ & $-0,3$ & $-0,3$ & $-0,3$ \\
\hline 2002 & $-0,1$ & 0 & 0,1 & 0,2 & 0,4 & 0,7 & $\mathbf{0 , 8}$ & 0,9 & 1 & 1,2 & 1,3 & 1,1 \\
\hline 2003 & $\mathbf{0 , 9}$ & 0,6 & 0,4 & 0 & $-0,3$ & $-0,2$ & 0,1 & 0,2 & 0,3 & 0,3 & 0,4 & 0,4 \\
\hline 2004 & 0,4 & 0,3 & 0,2 & 0,2 & 0,2 & 0,3 & 0,5 & 0,6 & 0,7 & 0,7 & 0,7 & 0,7 \\
\hline 2005 & 0,6 & 0,6 & 0,4 & 0,4 & 0,3 & 0,1 & $-0,1$ & $-0,1$ & $-0,1$ & $\begin{array}{l}-0,3 \\
\end{array}$ & $-0,6$ & $-0,8$ \\
\hline 2006 & $-0,9$ & $-0,8$ & $-0,6$ & $-0,4$ & $-0,1$ & 0 & 0,1 & 0,3 & 0,5 & $\mathbf{0 , 8}$ & 0,9 & 0,9 \\
\hline 2007 & 0,7 & 0,2 & $-0,1$ & $-0,3$ & $-0,4$ & \begin{tabular}{c|}
$-0,5$ \\
\end{tabular} & $-0,6$ & $\begin{array}{l}-0,8 \\
\end{array}$ & $-1,1$ & $-1,3$ & $-1,5$ & $-1,6$ \\
\hline 2008 & $-1,6$ & $-1,5$ & \begin{tabular}{ll|}
$-1,3$ \\
\end{tabular} & -1 & $\begin{array}{l}\mathbf{- 0 , 8} \\
\end{array}$ & $\begin{array}{c}-0,6 \\
\end{array}$ & $-0,4$ & $-0,2$ & $-0,2$ & $\begin{array}{l}-0,4 \\
\end{array}$ & $-0,6$ & $-0,7$ \\
\hline 2009 & $-\mathbf{- 0 , 8}$ & $-0,8$ & $-0,6$ & $-0,3$ & 0 & 0,3 & 0,5 & 0,6 & 0,7 & 1 & 1,4 & 1,6 \\
\hline 2010 & 1,5 & 1,2 & 0,8 & 0,4 & $-0,2$ & 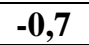 & -1 & $-1,3$ & $-1,6$ & $-1,6$ & $-1,6$ & $-1,6$ \\
\hline 2011 & $-1,4$ & $-1,2$ & $-0,9$ & $\begin{array}{l}-0,7 \\
\end{array}$ & $\begin{array}{c}-0,6 \\
\end{array}$ & $-0,4$ & $-0,5$ & $-0,6$ & $\begin{array}{l}-0,8 \\
\end{array}$ & -1 & $-1,1$ & -1 \\
\hline 2012 & $-0,9$ & $-0,7$ & $-0,6$ & $-0,5$ & $-0,3$ & 0 & 0,2 & 0,4 & 0,4 & 0,3 & 0,1 & $-0,2$ \\
\hline 2013 & $-0,4$ & $-0,4$ & $-0,3$ & $-0,3$ & $-0,4$ & $-0,4$ & $-0,4$ & $\begin{array}{l}-0,3 \\
\end{array}$ & $-0,3$ & $-0,2$ & $-0,2$ & $-0,3$ \\
\hline 2014 & $-0,4$ & $-0,5$ & $-0,3$ & 0 & 0,2 & 0,2 & 0 & 0,1 & 0,2 & 0,5 & 0,6 & 0,7 \\
\hline 2015 & $\mathbf{0 , 5}$ & 0,5 & 0,5 & $\mathbf{0 , 7}$ & $\mathbf{0 , 9}$ & 1,2 & 1,5 & 1,9 & 2,2 & 2,4 & 2,6 & 2,6 \\
\hline 2016 & 2,5 & 2,1 & 1,6 & $\mathbf{0 , 9}$ & 0,4 & $-0,1$ & $-0,4$ & $-0,5$ & $-0,6$ & $\begin{array}{c}-0,7 \\
\end{array}$ & $\begin{array}{c}-0,7 \\
\end{array}$ & $-0,6$ \\
\hline 2017 & $-0,3$ & $-0,2$ & 0,1 & 0,2 & 0,3 & 0,3 & 0,1 & $-0,1$ & $-0,4$ & $-0,7$ & $-\mathbf{- 0 , 8}$ & -1 \\
\hline 2018 & $-0,9$ & $-0,9$ & $-\mathbf{- 0 , 7}$ & $-0,5$ & $-0,2$ & 0 & 0,1 & 0,2 & $\mathbf{0 , 5}$ & $\mathbf{0 , 8}$ & 0,9 & $\mathbf{0 , 8}$ \\
\hline 2019 & $\begin{array}{l}\mathbf{0 , 7} \\
\end{array}$ & 0,7 & 0,7 & 0,7 & $\mathbf{0 , 5}$ & $\begin{array}{l}\mathbf{0 , 5} \\
\end{array}$ & 0,3 & 0,1 & 0,2 & 0,3 & 0,5 & 0,5 \\
\hline 2020 & 0,5 & 0,5 & 0,4 & 0,2 & $-0,1$ & $-0,3$ & $-0,4$ & $-0,6$ & $-0,9$ & $-1,2$ & \begin{tabular}{l|l|}
$-1,3$ \\
\end{tabular} & $-1,2$ \\
\hline
\end{tabular}

Grape, a perennial garden plant, is the plant of the warmtemperate climate, but it is resistant to high and low temperatures (Kaymaz, 2005). In order for the grape to develop in a region, the average annual temperature must be $11-16^{0} \mathrm{C}$. The grape freezes when temperatures drop below $-20{ }^{\circ} \mathrm{C}$ (Zengin and Özbahçe, 2014). Viticulture in a region is mostly restricted to winter and spring late frosts (Kaymaz,2005). Grape can be grown without irrigation in regions where the total annual precipitation is $600 \mathrm{~mm}$. If the annual total precipitation above 900 $\mathrm{mm}$, it causes fungal diseases in the grape. The most suitable precipitations for viticulture are winter, early spring and post-harvest autumn. Spring and summer precipitation cause diseases in grape (Zengin and Özbahçe, 2014). Between 1991 and 2020, Mediterranean Region (12\%) ranks 3rd in grape production in Turkey. $43 \%$ of grape production in the Mediterranean region is grown in Mersin (TUIK,2017; TUIK 2021) (Table 5).

Yield, production, area information of crops were obtained from Turkish Statistical Institute (TUIK, 2017, 2021); phenology information from were obtained from the Phenology Atlas of Turkey and literatures (Temuçin, 1993; Phenology Atlas of Turkey 2001,2014; Efe et al., 2009); monthly minimum, average, maximum temperature, and total precipitation climate data were obtained from meteorological stations (MGM, 2021).
Table 3. Olive area (decare), production (tone), and average yield per tree $(\mathrm{kg})$ value in Mediterranean Region

\begin{tabular}{llll}
\hline Province & $\begin{array}{l}\text { Area } \\
\text { (decare) }\end{array}$ & $\begin{array}{l}\text { Production } \\
\text { (tone) }\end{array}$ & $\begin{array}{l}\text { Average } \\
\text { Yield per } \\
\text { Tree }(\mathrm{kg})\end{array}$ \\
\hline Adana & 69321 & 20630 & 24 \\
Antalya & 120419 & 45327 & 18 \\
Burdur & 986 & 295 & 6 \\
Hatay & 386396 & 103854 & 15 \\
Isparta & 717 & 332 & 21 \\
Kahramanmaraş & 55774 & 5895 & 8 \\
Mersin & 212361 & 80111 & 24 \\
Osmaniye & 63294 & 24325 & 24 \\
\hline Total & 909266 & 280768 & 17 \\
\hline
\end{tabular}

Table 4. Cotton area (decare), production (tone), and yield ( $\mathrm{kg} /$ decare) value in Mediterranean Region

\begin{tabular}{llll} 
Province & $\begin{array}{l}\text { Area } \\
\text { (decare) }\end{array}$ & $\begin{array}{l}\text { Production } \\
\text { (tone) }\end{array}$ & $\begin{array}{l}\text { Yield } \\
\text { (kg/decare) }\end{array}$ \\
\hline Adana & 569518 & 205319 & 361 \\
Antalya & 107796 & 36631 & 340 \\
Hatay & 530686 & 215363 & 406 \\
Kahramanmaraş & 107866 & 36611 & 339 \\
Mersin & 84346 & 25531 & 303 \\
Osmaniye & 23453 & 5168 & 220 \\
\hline Total & 1423665 & 524622 & 369 \\
\hline
\end{tabular}


Table 5. Grape area (decare), production (tone), and yield (kg/ decare) values in Mediterranean Region

\begin{tabular}{llll} 
Province & $\begin{array}{l}\text { Area } \\
\text { (decare) }\end{array}$ & $\begin{array}{l}\text { Production } \\
\text { (tone) }\end{array}$ & $\begin{array}{l}\text { Yield (kg/ } \\
\text { decare) }\end{array}$ \\
\hline Adana & 47902 & 27104 & 566 \\
Antalya & 21269 & 22669 & 1066 \\
Burdur & 25596 & 16076 & 628 \\
Hatay & 46684 & 48337 & 1035 \\
Isparta & 65109 & 47077 & 723 \\
Kahramanmaraş & 231601 & 134771 & 582 \\
Mersin & 200340 & 228471 & 1140 \\
Osmaniye & 6914 & 5138 & 743 \\
\hline Total & 645414 & 529644 & 821 \\
\hline
\end{tabular}

\section{Methods}

First of all, the trend analysis of the yield values of the crops was examined. According to the findings obtained from IPCC reports, after the 2000s, the effects of climate change, especially in the Mediterranean Basin, affected many physical and human environments, primarily agriculture (Iglesias et al. 2011; Stone et al., 2013, del Pozo et al. 2019; Abd-Elmabod et al. 2020; Ustaoğlu et al., 2021). In order to see this effect in the trend in crop yields, Mann Kendall Trend analysis was applied to yield values. Statistically, the year u (ti) and $\mathrm{u}^{\prime}(\mathrm{ti})$ values intersect was determined as the year in which the variability in yield occurred. The Mann-Kendall test consists in calculating two series of statistical values, one from the beginning of the series, the second from the end. These series are shown in the form of two curves respectively called the direct curve (ui) and the backward curve (u'i). A trend is significant when the curve ui exceeds the $5 \%$ threshold, i.e. when |ui $\mid>1.96$. Significance of trends were evaluated at the 0.05 levels. Sneyers (1990) demonstrated the usefulness of this test, using its direct progressive and backward forms, for identifying the intervals in which trends are most pronounced, and trend turning points and/or climate shifts. The point which marks the beginning of the change corresponds to the intersection between the direct curve and the backward curve, (u'i ) . Graphically, the backward and direct curves are often confused when there is no significant trend in the series (Sneyers 1990; Yue et al., 2002, Samba and Nganga, 2012 Ustaoğlu, 2013). Secondly; according to the findings obtained, the relationship between index values and yield values according to phenological periods before and after the change was analyzed by applying the Spearman Correlation Coefficient at the significance level of $\mathrm{p} \leq$ 0.05 and $\mathrm{p} \leq 0.00$. Both (lag 0) and (lag -1$)$ time series were analysed but (lag 0) gives the best results and just (lag 0) used in this study. Strong El Nino years and yield values were plotted on the same graph, and the changes in yield were tried to be explained according to the phenology of the crops.

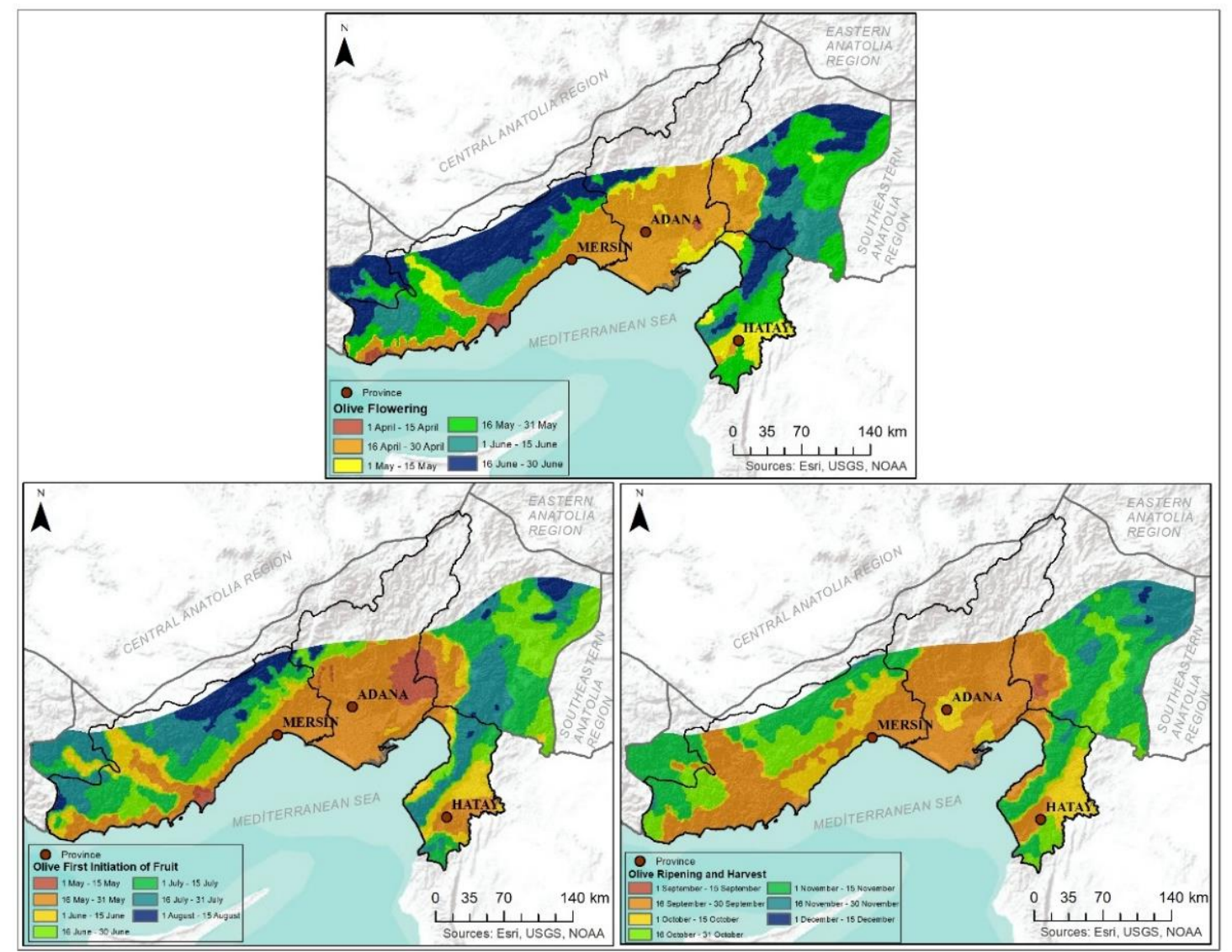

Fig. 2. Phenological stage of olive in the Mediterranean Region (Source: Map revised from Phenology Atlas of Turkey, 2014) 


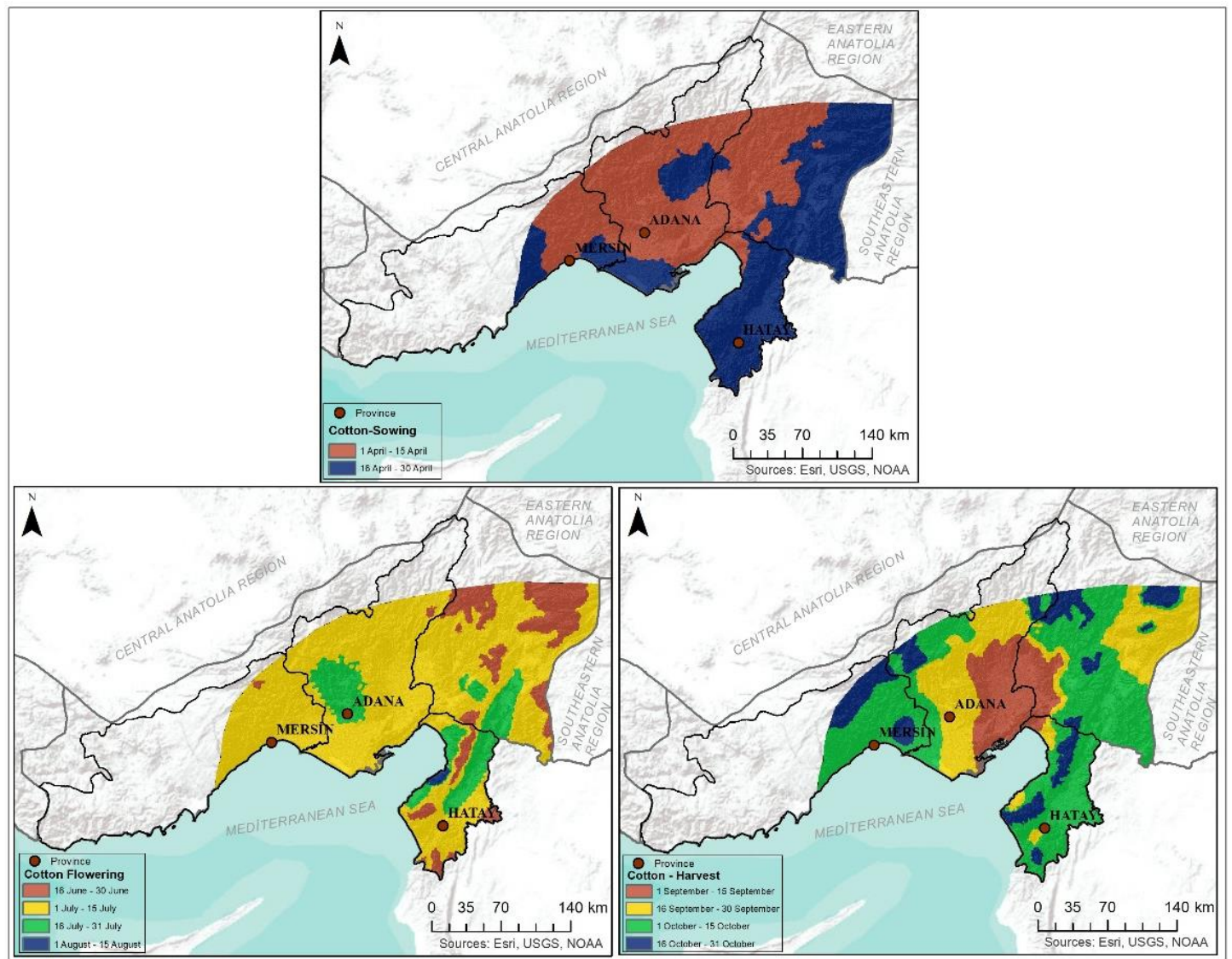

Fig. 3. Phenological stage of cotton in the Mediterranean Region (Source: Map revised from Phenology Atlas of Turkey, 2014)

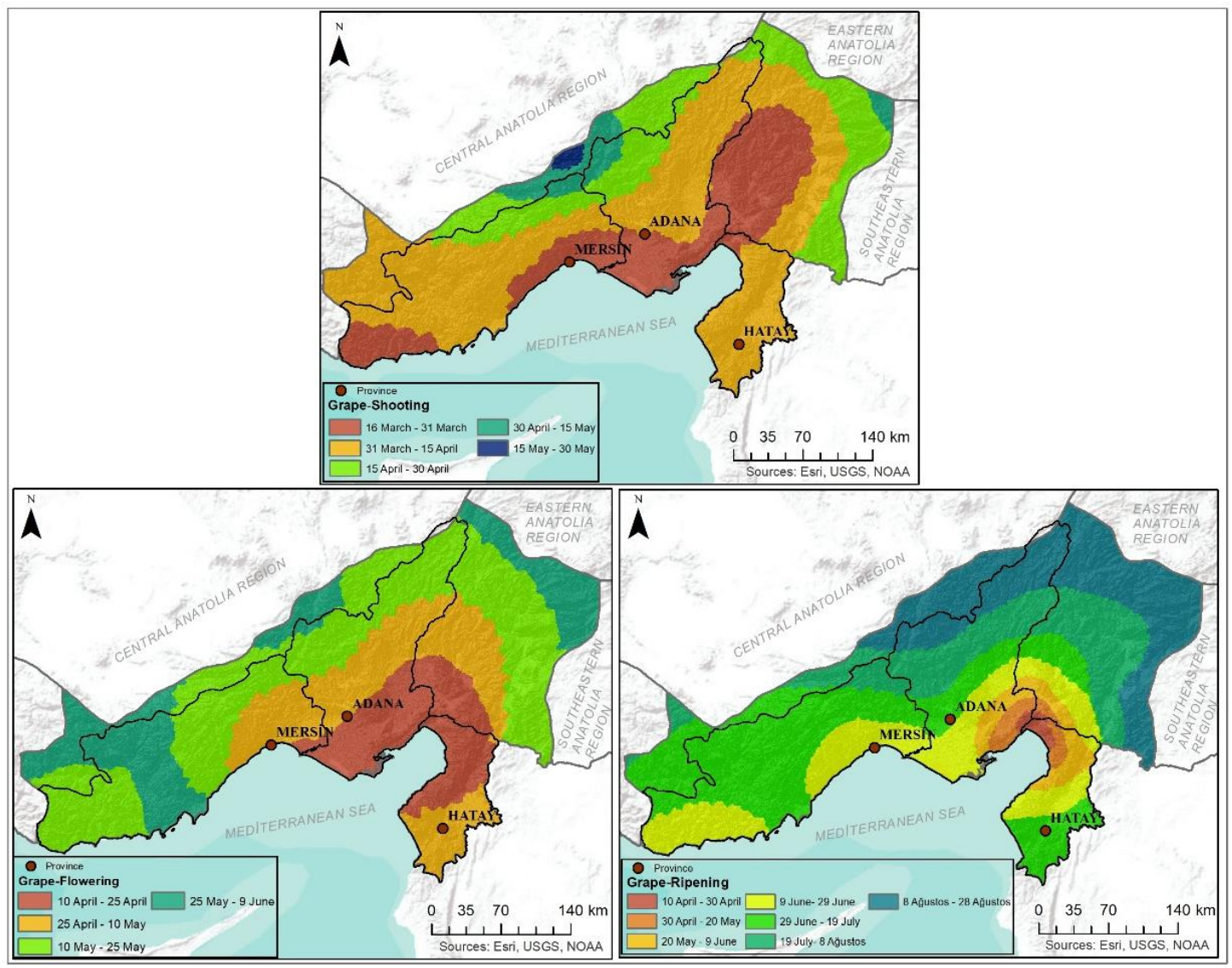

Fig. 4. Phenological stage of grape in the Mediterranean Region (Source: Map revised from Phenology Atlas of Turkey, 2001). 
For the Spearman Correlation coefficient analysis of the crops, the phenological periods suitable for the Mediterranean Region were determined. In this study, phenology maps were rearranged according to the region from the phenology atlas of Turkey belonging to the Turkish State Meteorological Service in Turkey. According to this, the phenological periods of olive in Hatay are flowering between 16 April - 30 June, the first initiation fruit between 16 May - 15 July, ripening and harvesting between 16 September and 15 November. The phenological stages of cotton are sowing, flowering, and harvesting. Sowing in the Adana is between 1 April - 30 April, flowering between 1 July - 31 July, harvest between 16 August - 31 October (Phenology Atlas of Turkey, 2014). The phenological stages of grape are shooting, flowering and ripening The phenological periods of Grape in Mersin are shooting 16 March - 15 May, flowering 10 April - 9 June, and fruit ripening between 9 June - 8 August (Phenology Atlas of Turkey, 2001) (Fig. 2-3-4). The statistical relationship between indices and yields was determined by Spearman correlation coefficient analysis, and the significance of the results was measured with the value $\mathrm{p} \leq 0.05$ and $\mathrm{p} \leq$ 0.00 .

\section{Discussion and Results}

\section{Mann Kendall Rank Correlation Trend Test Results}

Mann Kendall trend analysis was applied to the yield values of the crops in the period 1991-2020. Olive yield trend has changed in 2001. Because $\mathrm{u}$ (ti) and $\mathrm{u}^{\prime}(\mathrm{ti})$ values intersected in 2001 (Fig. 5), accordingly, there is an increasing trend in olive yield, and it's u (ti) value is 4,34 (Table 6).

Cotton yield trend has changed in 2002. Because u (ti) and $\mathrm{u}^{\prime}$ (ti) values intersected in 2002 (Fig. 6), accordingly, there is an increasing trend in cotton yield, and it's $\mathrm{u}(\mathrm{ti})$ value is 5.91 .

Grape yield trend has changed in 2005. Because u (ti) and $\mathrm{u}^{\prime}$ (ti) values intersected in 2005 (Fig. 7), accordingly, there is an increasing trend in grape yield, and it's u (ti) value is 6,48 .

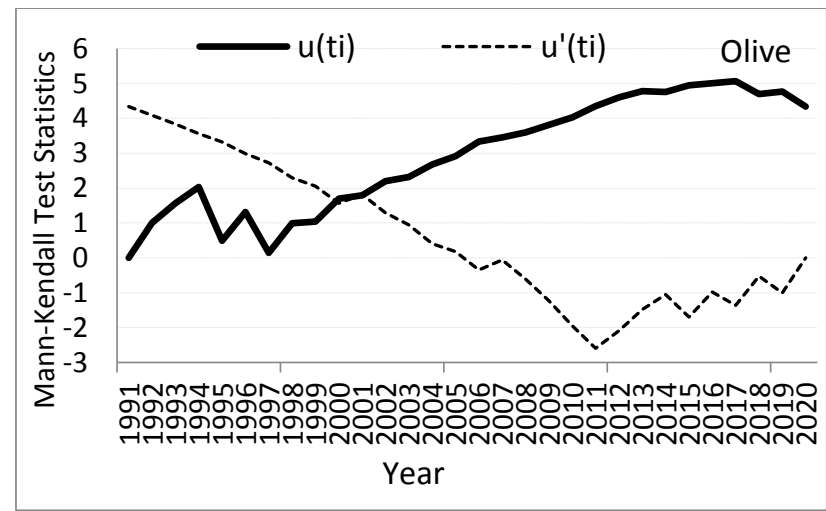

Fig.5. Mann Kendall Rank Correlation Trend Test results of olive yield

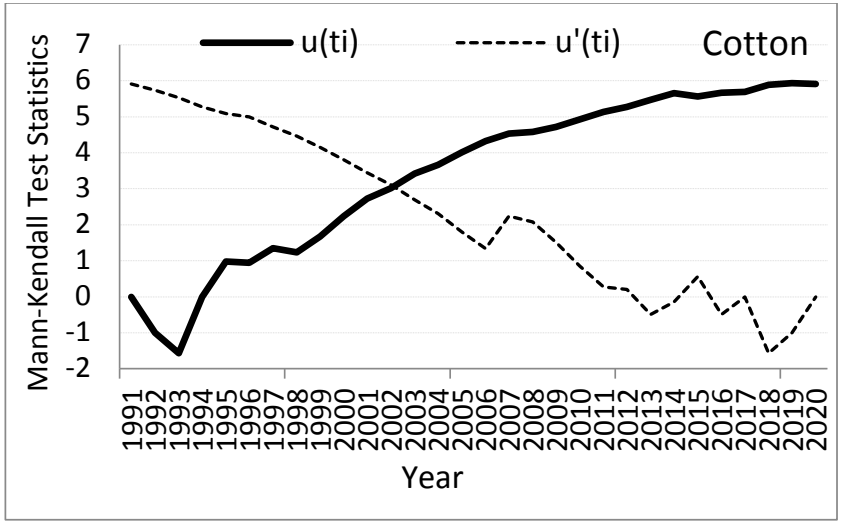

Fig. 6. Mann Kendall Rank Correlation Trend Test results of cotton yield

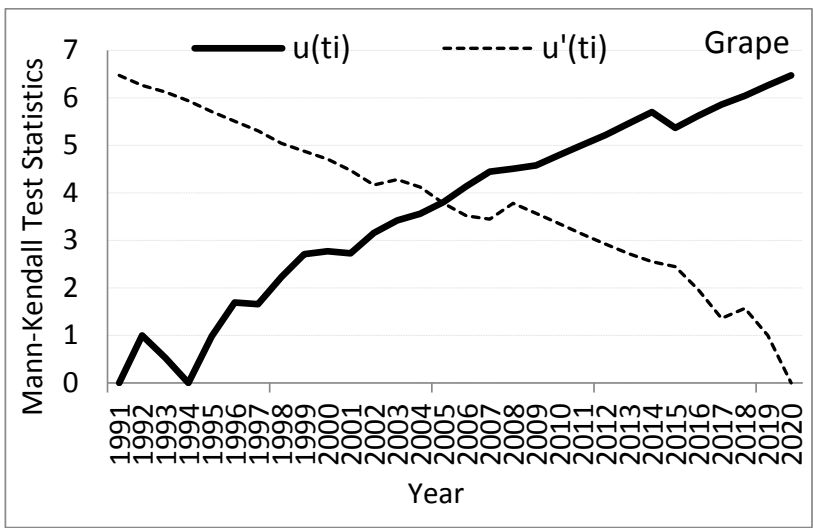

Fig. 7. Mann Kendall Rank Correlation Trend Test results of grape yield

Table 6. Mann Kendall Rank Correlation Trend Test Statistic Results of Crops

\begin{tabular}{lccccc}
\hline \multicolumn{5}{c}{ Mann Kendall Rank Correlation Trend Test } \\
\hline Crops & $\begin{array}{c}\text { Time } \\
\text { Series }\end{array}$ & $\mathbf{u}(\mathbf{t})$ & $\begin{array}{c}\text { Trend } \\
\text { level (95 } \\
\text { \%) }\end{array}$ & $\begin{array}{c}\text { Trend } \\
\text { year }\end{array}$ & $\begin{array}{c}\text { N } \\
\text { (year) }\end{array}$ \\
\hline Olive & Yield & $\underline{4,34}$ & Increasing & 2001 & 30 \\
Cotton & Yield & $\underline{\underline{5,91}}$ & Increasing & 2002 & 30 \\
Grape & Yield & $\underline{6,48}$ & Increasing & 2005 & 30 \\
\hline
\end{tabular}

\section{Results of Correlation Between Atmospheric Indices} and Crop Yields in the Phenological Periods

Olive was examined by divided it into three periods as 1991-2001, 2002-2020, and 1991-2020 according to Mann Kendall Rank Correlation Trend Test results. The statistical relationship between Nino 3, Nino 3.4, Nino 4, and NAO indices at $\mathrm{p} \leq 0.05$ and $\mathrm{p} \leq 0.00$ significance level according to the phenological period of olive yield was analyzed. Accordingly, the most significant relationship was found in 1991-2001 with Nino 3.4 and Nino 4 during the flowering period and the first initiation fruit. Significant correlations were found with Nino 3.4 at at $\mathrm{R}=0.70 \mathrm{p} \leq 0.02$ during first initiation fruit. Nino 4 with $\mathrm{R}=0.65 \mathrm{p} \leq 0.03$ and $\mathrm{R}=0.81 \mathrm{p} \leq 0.00$ during flowering and $\mathrm{R}=0.65 \mathrm{p} \leq 0.03$ during the first initiation fruit. A significant relationship was found between $\mathrm{R}=0.81 \mathrm{p} \leq 0.00$. 
There was no significant relationship between index values and yield in the period 2002-2020. In the period 1991-2020, a significant relationship was obtained between Nino 4 and $R=0.40 p \leq 0.03$ and $R=0.36 p$ $\leq 0.05$ (Table 7).

Cotton was analyzed by divided it into three periods as 1991-2002, 2003-2020, and 1991-2020 according to the Mann Kendall Rank Correlation Trend Test results. The statistical relationship between Nino 3, Nino 3.4, Nino 4, and NAO indices at $\mathrm{p} \leq 0.05$ and $\mathrm{p} \leq 0.00$ significance level according to the phenological period of cotton yield was investigated. Accordingly, the most significant relationship was found in 1991-2002, with Nino 3.4 in the sowing period. A significant relationship was found with Nino 3.4 at the level of $R=0.64 p \leq 0.03$ in the sowing period. There was no significant relationship between indicevalues and yield in the 2003-2020 period. In the period 1991-2020, a significant relationship was obtained with NAO at the level of $\mathrm{R}=0.37 \mathrm{p} \leq 0.05$ (Table 8). Grape was divided into three periods as 19912005, 2006-2020, and 1991-2020 according to the Mann Kendall Rank Correlation Trend Test results. The statistical relationship between Nino 3, Nino 3.4, Nino 4, and NAO indices at $\mathrm{p} \leq 0.05$ and $\mathrm{p} \leq 0.00$ significance level according to the phenological period of grape yield was investigated. Accordingly, there was no significant relationship between indices and yield in the period 1991-2005. From 2006 to 2020, a significant relationship was found with Nino 3, Nino 4, and NAO in the phenological period. There was no significant relationship between indicevalues and yield in the 19912005 and 1991-2020 period. In the period 2006-2020, significant correlations were found with Nino 3 at $\mathrm{R}=$ $0.58 \mathrm{p} \leq 0.02$, with Nino 4 at the level of $\mathrm{R}=0.53 \mathrm{p} \leq$ $0.04, \mathrm{R}=0.57 \mathrm{p} \leq 0.03, \mathrm{R}=0.64 \mathrm{p} \leq 0.01, \mathrm{R}=0.60 \mathrm{p}$ $\leq 0.02$ and with NAO at the level of $\mathrm{R}=0.54 \mathrm{p} \leq 0.05$ (Table 9)

Table 7. Result of Spearman Correlation Coefficient Analysis between Atmospheric Indices and Olive Yield Values in Hatay

\begin{tabular}{|c|c|c|c|c|c|c|c|c|c|c|c|c|}
\hline \multicolumn{13}{|c|}{ Phenological Period of the Olive } \\
\hline \multirow{2}{*}{ Period } & \multirow{2}{*}{ Indice } & \multirow{2}{*}{$\begin{array}{l}\text { Correlation } \\
\text { and Sig. } \\
\text { Level }\end{array}$} & \multicolumn{3}{|c|}{ Flowering } & \multicolumn{3}{|c|}{ First Initation of Fruit } & \multicolumn{3}{|c|}{ Ripening and Harvest } & \multirow[t]{2}{*}{ Year } \\
\hline & & & IV & $\mathbf{V}$ & VI & $\mathbf{v}$ & VI & VII & IX & $\mathbf{x}$ & XI & \\
\hline \multirow{8}{*}{ 1991-2001 } & \multirow{2}{*}{ Nino3 } & $\mathbf{R}$ & $-0,04$ & $-0,10$ & $-0,52$ & $-0,10$ & $-0,52$ & $-0,56$ & $-0,32$ & $-0,35$ & $-0,35$ & $-0,36$ \\
\hline & & $\mathbf{P}$ & 0,92 & 0,77 & 0,10 & 0,77 & 0,10 & 0,07 & 0,34 & 0,29 & 0,29 & 0,27 \\
\hline & \multirow{2}{*}{ Nino 3.4} & $\mathbf{R}$ & $-0,21$ & $-0,38$ & $-0,70 *$ & $-0,38$ & $-0,70^{*}$ & $-0,59$ & $-0,44$ & $-0,46$ & $-0,44$ & $-0,58$ \\
\hline & & $\mathbf{P}$ & 0,54 & 0,25 & $\mathbf{0 , 0 2}$ & 0,25 & $\mathbf{0 , 0 2}$ & 0,06 & 0,18 & 0,16 & 0,17 & 0,06 \\
\hline & \multirow{2}{*}{ Nino 4} & $\mathbf{R}$ & $-0,79 *$ & $-0,81 *$ & $-0,65 *$ & $-0,81 *$ & $-0,65 *$ & $-0,48$ & $-0,56$ & $-0,44$ & $-0,42$ & $-0,66 *$ \\
\hline & & $\mathbf{P}$ & $\mathbf{0 , 0 0}$ & $\mathbf{0 , 0 0}$ & $\mathbf{0 , 0 3}$ & $\mathbf{0 , 0 0}$ & $\mathbf{0 , 0 3}$ & 0,14 & 0,08 & 0,17 & 0,2 & $\mathbf{0 , 0 3}$ \\
\hline & \multirow{2}{*}{ NAO } & $\mathbf{R}$ & $-0,09$ & 0,25 & 0,41 & 0,25 & 0,41 & 0,04 & $-0,09$ & 0,73* & $-0,03$ & 0,17 \\
\hline & & $\mathbf{P}$ & 0,79 & 0,47 & 0,20 & 0,47 & 0,20 & 0,91 & 0,79 & $\mathbf{0 , 0 1}$ & 0,94 & 0,62 \\
\hline $2002-2020$ & \multicolumn{12}{|c|}{ No significant result at $\alpha<0.05$ level. } \\
\hline \multirow{8}{*}{ 1991-2020 } & \multirow{2}{*}{ Nino3 } & $\mathbf{R}$ & $-0,09$ & $-0,14$ & $-0,1$ & $-0,14$ & $-0,1$ & $-0,05$ & 0,12 & 0,04 & 0 & $-0,06$ \\
\hline & & $\mathbf{p}$ & 0,65 & 0,44 & 0,59 & 0,44 & 0,59 & 0,79 & 0,52 & 0,83 & 0,99 & 0,77 \\
\hline & \multirow{2}{*}{ Nino 3.4} & $\mathbf{R}$ & $-0,28$ & $-0,24$ & $-0,26$ & $-0,24$ & $-0,26$ & $-0,16$ & 0,07 & $-0,03$ & $-0,01$ & $-0,16$ \\
\hline & & $\mathbf{p}$ & 0,13 & 0,21 & 0,16 & 0,21 & 0,16 & 0,39 & 0,73 & 0,89 & 0,96 & 0,39 \\
\hline & \multirow{2}{*}{ Nino 4} & $\mathbf{R}$ & $-0,40 *$ & $-0,36^{*}$ & $-0,32$ & $-0,36^{*}$ & $-0,32$ & $-0,22$ & $-0,04$ & $-0,07$ & 0 & $-0,21$ \\
\hline & & $\mathbf{p}$ & $\mathbf{0 , 0 3}$ & $\mathbf{0 , 0 5}$ & 0,08 & $\mathbf{0 , 0 5}$ & 0,08 & 0,24 & 0,83 & 0,71 & 0,99 & 0,27 \\
\hline & \multirow{2}{*}{ NAO } & $\mathbf{R}$ & 0,09 & 0,26 & 0,06 & 0,26 & 0,06 & $-0,14$ & $-0,01$ & $-0,04$ & $\begin{array}{l}0,09 \\
\end{array}$ & $-0,04$ \\
\hline & & p & 0,64 & 0,18 & 0,75 & 0,18 & 0,75 & 0,47 & 0,95 & 0,82 & 0,63 & 0,85 \\
\hline
\end{tabular}

* Correlation is significant at the $\mathbf{p} \leq \mathbf{0 . 0 5}$ level

Table 8. Result of Spearman Correlation Coefficient Analysis between Atmospheric Indices and Cotton Yield Values in Adana

\begin{tabular}{|c|c|c|c|c|c|c|c|c|}
\hline \multicolumn{9}{|c|}{ Phenological Period of the Cotton } \\
\hline \multirow{2}{*}{ Period } & \multirow{2}{*}{ Indice } & \multirow{2}{*}{$\begin{array}{c}\text { Correlation } \\
\text { and Sig. Level }\end{array}$} & \multirow{2}{*}{$\frac{\text { Sowing }}{\text { IV }}$} & \multirow{2}{*}{$\frac{\text { Flowering }}{\text { VII }}$} & \multicolumn{3}{|c|}{ Harvest } & \multirow{2}{*}{ Year } \\
\hline & & & & & VIII & IX & $\mathbf{X}$ & \\
\hline \multirow{8}{*}{ 1991-2002 } & \multirow{2}{*}{ Nino3 } & $\mathbf{R}$ & $-0,36$ & $-0,2$ & $-0,22$ & $-0,22$ & $-0,12$ & $-0,21$ \\
\hline & & $\mathbf{p}$ & 0,25 & 0,54 & 0,5 & 0,48 & 0,71 & 0,51 \\
\hline & \multirow{2}{*}{ Nino 3.4} & $\mathbf{R}$ & $-0,64 *$ & $-0,16$ & $-0,11$ & $-0,09$ & $-0,04$ & $-0,25$ \\
\hline & & $\mathbf{p}$ & $\mathbf{0 , 0 3}$ & 0,62 & 0,73 & 0,78 & 0,9 & 0,43 \\
\hline & \multirow{2}{*}{ Nino 4} & $\mathbf{R}$ & $-0,21$ & 0,02 & $-0,09$ & 0,01 & $-0,07$ & $-0,13$ \\
\hline & & $\mathbf{p}$ & 0,51 & 0,95 & 0,78 & 0,98 & 0,83 & 0,7 \\
\hline & \multirow{2}{*}{ NAO } & $\mathbf{R}$ & $-0,23$ & 0,04 & $-0,33$ & $-0,02$ & 0,13 & $-0,34$ \\
\hline & & $\mathbf{p}$ & 0,48 & 0,91 & 0,29 & 0,94 & 0,68 & 0,28 \\
\hline 2003-2020 & \multicolumn{8}{|c|}{ No significant result at $\alpha<0.05$ level. } \\
\hline \multirow{8}{*}{ 1991-2020 } & \multirow{2}{*}{ Nino3 } & $\mathbf{R}$ & $-0,05$ & $-0,05$ & $-0,07$ & 0,01 & 0,02 & $-0,18$ \\
\hline & & $\mathbf{p}$ & 0,79 & 0,78 & 0,7 & 0,97 & 0,91 & 0,33 \\
\hline & \multirow{2}{*}{ Nino 3.4} & $\mathbf{R}$ & $-0,14$ & $-0,12$ & $-0,13$ & $-0,01$ & 0,00 & $-0,16$ \\
\hline & & $\mathbf{p}$ & 0,45 & 0,52 & 0,48 & 0,96 & 0,99 & 0,39 \\
\hline & \multirow{2}{*}{ Nino 4} & $\mathbf{R}$ & 0,05 & $-0,01$ & 0,01 & 0,07 & 0,11 & 0,02 \\
\hline & & $\mathbf{p}$ & 0,81 & 0,95 & 0,97 & 0,7 & 0,57 & 0,9 \\
\hline & \multirow{2}{*}{ NAO } & $\mathbf{R}$ & $-0,13$ & 0,04 & $-0,11$ & $0,37 *$ & $-0,1$ & 0,15 \\
\hline & & $\mathbf{p}$ & 0,51 & 0,85 & 0,57 & $\mathbf{0 , 0 5}$ & 0,59 & 0,44 \\
\hline
\end{tabular}


Table 9. Result of Spearman Correlation Coefficient Analysis between Atmospheric Indices and Grape Yield Values in Mersin

\begin{tabular}{|c|c|c|c|c|c|c|c|c|c|c|c|c|}
\hline \multicolumn{13}{|c|}{ Phenological Period of the Grape } \\
\hline \multirow[t]{2}{*}{ Period } & \multirow[t]{2}{*}{ Indice } & \multirow[t]{2}{*}{ Correlation and Sig. Level } & \multicolumn{3}{|c|}{ Shooting } & \multicolumn{3}{|c|}{ Flowering } & \multicolumn{3}{|c|}{ Ripening } & \multirow[t]{2}{*}{ Year } \\
\hline & & & III & IV & $\mathbf{V}$ & IV & $\mathbf{V}$ & VI & VI & VII & VIII & \\
\hline 1991-2005 & \multicolumn{12}{|c|}{ No significant result at $\alpha<0.05$ level. } \\
\hline \multirow[t]{8}{*}{ 2006-2020 } & \multirow[t]{2}{*}{ Nino3 } & $\mathbf{R}$ & 0,3 & 0,49 & $\mathbf{0 , 5 8 *}$ & 0,49 & $\mathbf{0 , 5 8 *}$ & 0,24 & 0,24 & 0,2 & 0,04 & 0,24 \\
\hline & & $\mathbf{p}$ & 0,27 & 0,07 & $\mathbf{0 , 0 2}$ & 0,07 & $\mathbf{0 , 0 2}$ & 0,38 & 0,38 & 0,47 & 0,9 & 0,39 \\
\hline & \multirow[t]{2}{*}{ Nino 3.4} & $\mathbf{R}$ & 0,43 & 0,47 & 0,5 & 0,47 & 0,5 & 0,49 & 0,49 & 0,45 & 0,29 & 0,37 \\
\hline & & $\mathbf{p}$ & 0,11 & 0,08 & 0,06 & 0,08 & 0,06 & 0,06 & 0,06 & 0,09 & 0,3 & 0,17 \\
\hline & \multirow[t]{2}{*}{ Nino 4} & $\mathbf{R}$ & 0,45 & $0,53 *$ & $0,57 *$ & $0,53 *$ & $0,57 *$ & $0,64 *$ & $0,64 *$ & $0,60 *$ & 0,44 & 0,53* \\
\hline & & $\mathbf{p}$ & 0,09 & 0,04 & $\mathbf{0 , 0 3}$ & 0,04 & $\mathbf{0 , 0 3}$ & $\mathbf{0 , 0 1}$ & $\mathbf{0 , 0 1}$ & 0,02 & 0,1 & 0,04 \\
\hline & \multirow[t]{2}{*}{ NAO } & $\mathbf{R}$ & $0,54 *$ & 0,13 & $-0,06$ & 0,13 & $-0,06$ & $-0,07$ & $-0,07$ & 0,21 & 0,25 & 0,29 \\
\hline & & $\mathbf{p}$ & $\mathbf{0 , 0 5}$ & 0,65 & 0,85 & 0,65 & 0,85 & 0,81 & 0,81 & 0,48 & 0,39 & 0,32 \\
\hline 1991-2020 & \multicolumn{12}{|c|}{ No significant result at $\alpha<0.05$ level. } \\
\hline
\end{tabular}

According to the results, the most significant relationship between indices and yields was found in general El Nino indices and especially in Nino 3.4. The most statistically significant relationship was determined in the period 1991-2001, before the trend for olives began to change. For cotton, it was determined throughout the period examined 1991-2002 and 1991-2020. A statistically significant relationship was found for grapes in 20062020 .

Correlation coefficients obtained with El Nino indices in phenological periods were more effective than the NAO indice. In this case, we can say that El Nino is more effective in terms of time and spatial yield efficiency in the south of Turkey than NAO.

\section{Effects of Extreme El Nino Phases on Crop Yields}

Particulary in the last 20-25 years, it has been stated that statistically significant relationships have been determined between atmospheric oscillations and climatic conditions (Price et al., 1998). The effect of El Nino years on precipitation variability in Turkey has been investigated (Türkeş, 1998, Karabörk and Kahya, 2003, Karabörk et al., 2005, Mart1, 2007, 2014). For countries in the Mediterranean Basin, such as Spain and Iran, there are studies on El Niño on precipitation variability (Nazemosadat and Cordery 2000, Hasanean, 2004, Vaquez et al., 2005). In these studies, it was stated that there were drought signals during the El Nino years (Vicente-Serrano 2005, Tosunoğlu et al. 2018, Dabanlı et al., 2017). It has been analyzed that extreme temperatures in Turkey are also affected by El Nino conditions (Martı and Kahya, 2007).

The first study investigating the effect of atmospheric oscillations on crop yield in Turkey is the relationship between hazelnut yield and the NAO index (Ustaoğlu, 2009). It has been determined that the effect of ENSO is more effective in the south, where NAO is generally more effective in the northern regions of Turkey (Diker et al., 2018). In this study that determined the relationship between olive yield and El Nino and NAO in Turkey, no significant relationship was found with NAO, but significant relationship and low yield was found in strong El Nino years (Uzun and Ustaoğlu, 2019). Another study that found statistically significant relationships between olive yield and Nino 3.4 indicewas applied in Northwest Africa (Abahous et al., 2021). It has been determined that there are significant statistical relationships between olive yield and Nino 3.4 in Iran (Bannayan et al., 2011). El Nino event has a negative effect on wheat yield in Morocco and Egypt, especially (Qian et al., 2020). Orange and tangerine yield in Spain are highly affected by ENSO (Gimeno et al., 2002). Relationships between soybean yields and El Nino Southern Oscillation (ENSO) phases in Eastern Paraguay and were investigated. According to El Nino years, a decrease in precipitation was observed between planting and flowering periods, and it was determined that the average amount of rainfall during the maturation period of the crops was lower than in El Nino years (Fraisse et al. 2008).

Olive is sensitive to high temperatures. It needs chilling for a certain period for flower bud formation from January to April. Although olives grow in tropical regions, the fruit cannot be formed because of the absence of the cooling period that olives need in the tropical climate (Temuçin, 1993). The frequency and severity of extreme events such as high temperatures, drought, and floods, which are thought to be caused by human-induced climate change after the 2000s in the Mediterranean region, negatively affect olive cultivation. 2020 has been the year with the most extreme events in Turkey, with 984 extreme events. There is a significant increase in extreme event trends, especially after 2000 (TC Ministry of Agriculture and Forestry, General Directorate of Meteorology, 2021). Extreme weather events have greatly affected olive yield. In addition to olive yield, it also caused changes in the quality of olive oil and the grain size of the olive. The increase in temperatures experienced during the flowering period seriously affected the production due to the burning and drying of the flowers. The 2020-2021 seasons has also been recorded in statistics when olive production in Turkey was the lowest for the last ten years (UZZK, 2020).

The chilling period of olive is in April (Temuçin, 1993; Efe et al., 2009). Considering the average, maximum, and minimum temperatures of April in this study area, it is observed that there is an increasing trend (Fig. 8a, 8b, $8 \mathrm{c})$. These values have also been determined at absolute 
temperatures. Considering the total monthly amount of precipitation in October, when olive need rainfall in their phenological period, a decreasing trend has been determined (Fig. 8d). In Hatay, where olive cultivation is most common, a decrease in yield has been observed by $15 \%$ compared to the average in the last ten years (20092020) and by $50 \%$ compared to the average in the last 20 years (2000-2020) (Fig. 9). There was no severe yield loss in cotton and grape, which were not affected much by high temperatures and low rainfall during their phenological period (Fig. 10-11). However, in 1997, there was a decrease in temperatures throughout Turkey, and this decrease was further strengthened by the El Nino event (Table 2). In 1997, there was a decrease in the crop yield in the phenological period of olive flowering and fruit formation in the grape and the sowing phenological period of cotton (Fig. 9-10-11). The last 5 years, from 2015 to the present, have been recorded as the hottest years since the Industrial
Revolution. Increasing temperatures and El Nino events etc., have affected the occurrence and frequency of extreme events such as intense rainfalls. During the harvest in September 2015, cotton was affected by heavy rain, and its yield decreased. In 2015, grape ripening phenological time was affected by heavy rainfall (Fig. $8 \mathrm{e}, 10,11)$. The El Nino in 2015 became more severe and effective in 2016 (Table 2), and this time caused a loss of yield in the olive during the phenological period (Fig. 9). 2016 was a year of both extreme temperatures and low precipitation. In September, the total rainfall was the lowest in this study period $(21.4 \mathrm{~mm})$ (Fig. 8d). Rainfall is one of the important climatic factors affecting olive yield. The low amount of precipitation causes the fruits to remain thin and decrease yield (Doğanay and Coşkun, 2012).This study determined that there were significant decreases in yield values, especially in 1997 and 2015-2016, which are the strong El Nino years according to the ONI (Table 2, Fig. 9-10-11).

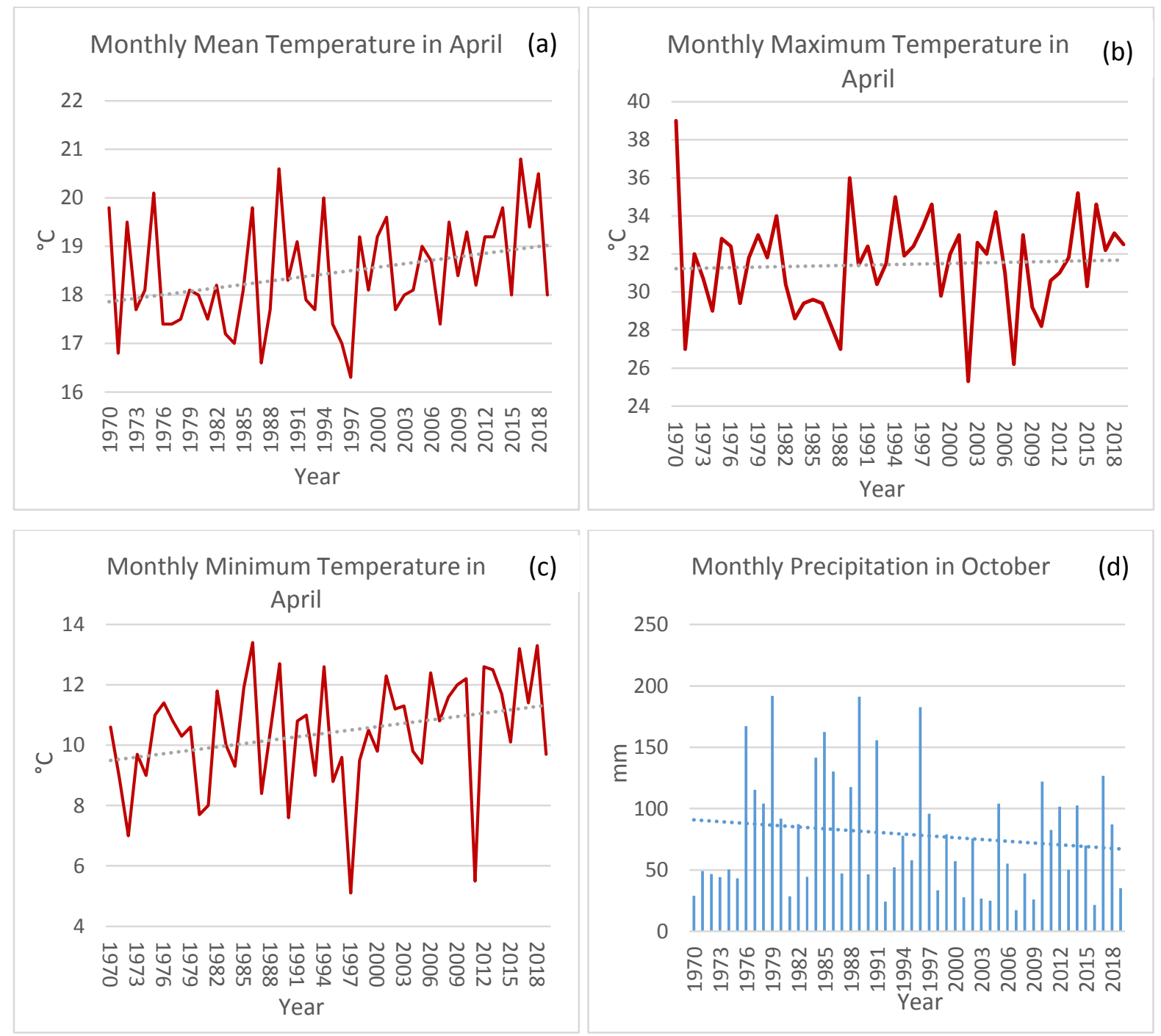

Fig. 8. a) Monthly Maximum Temperature in April, b) Monthly Mean Temperature in April, c) Monthly Minimum Temperature in April, d) Monthly Precipitation in October 
Monthly Precipitation in September

(e)

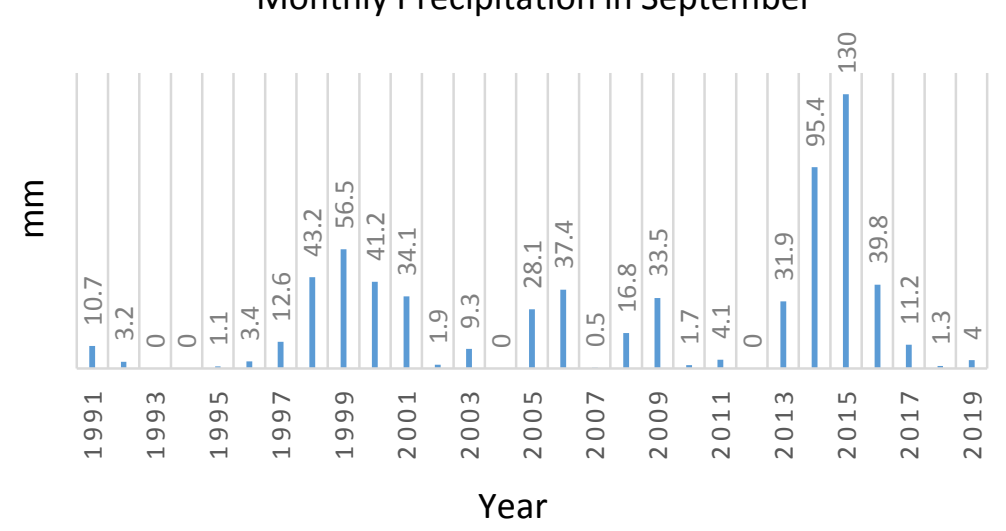

Fig. 8. e) Monthly Precipitation in September

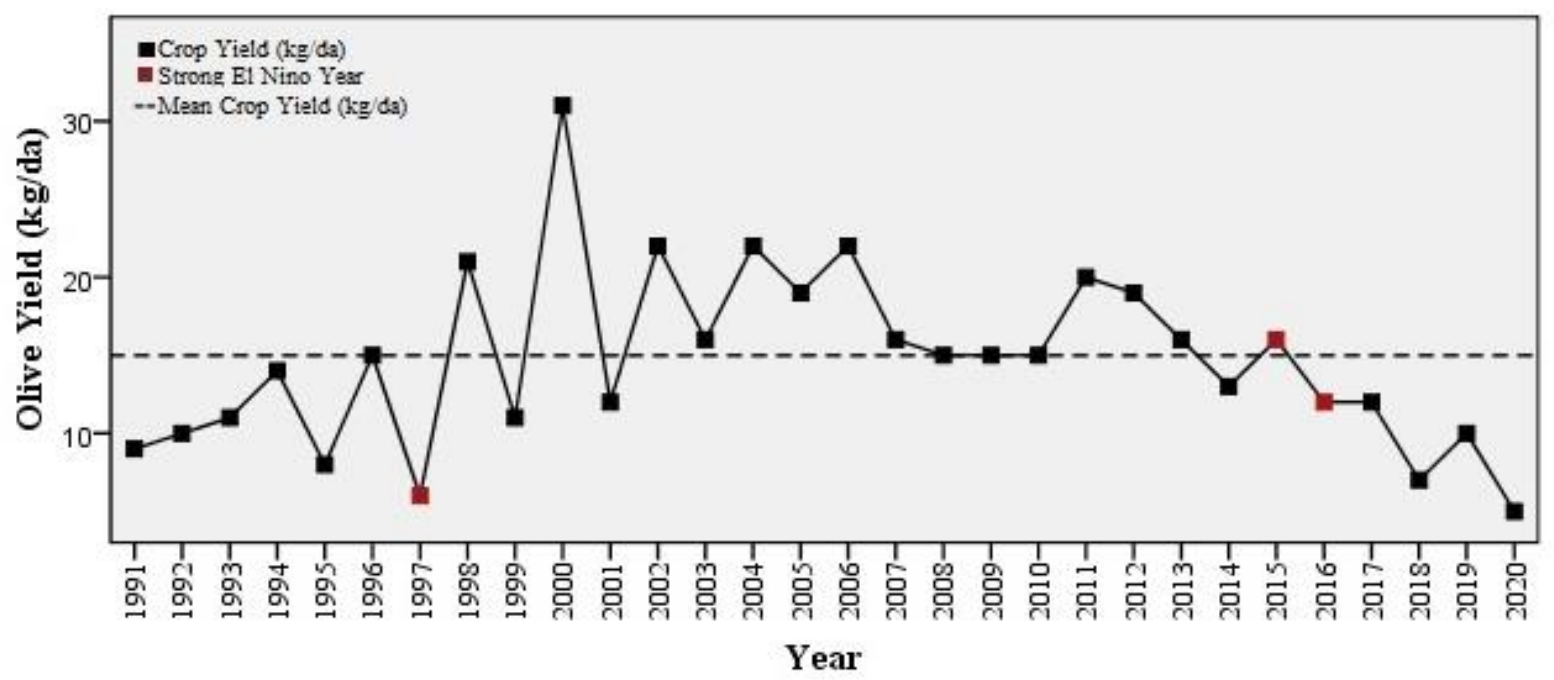

Fig. 9. Phenological year of Olive Yield in Hatay

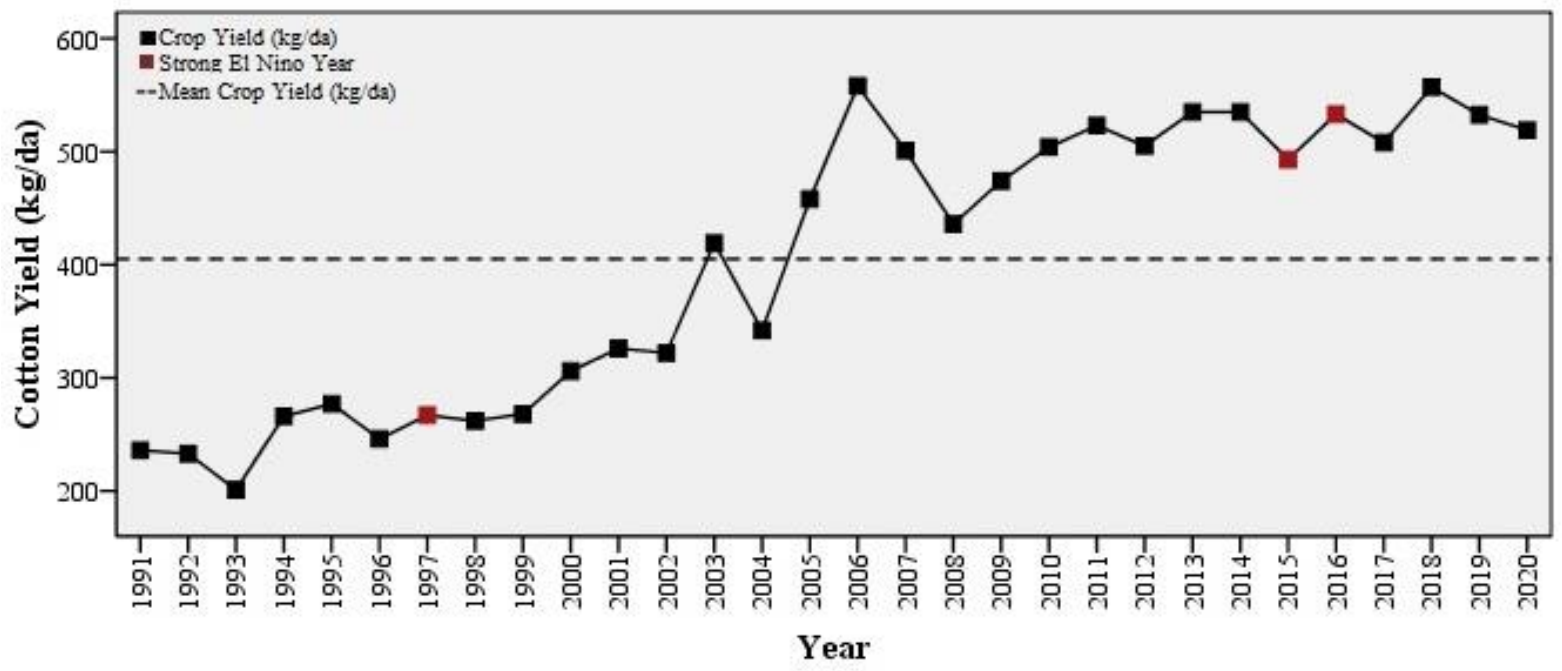

Fig. 10. Phenological year of Cotton Yield in Adana 


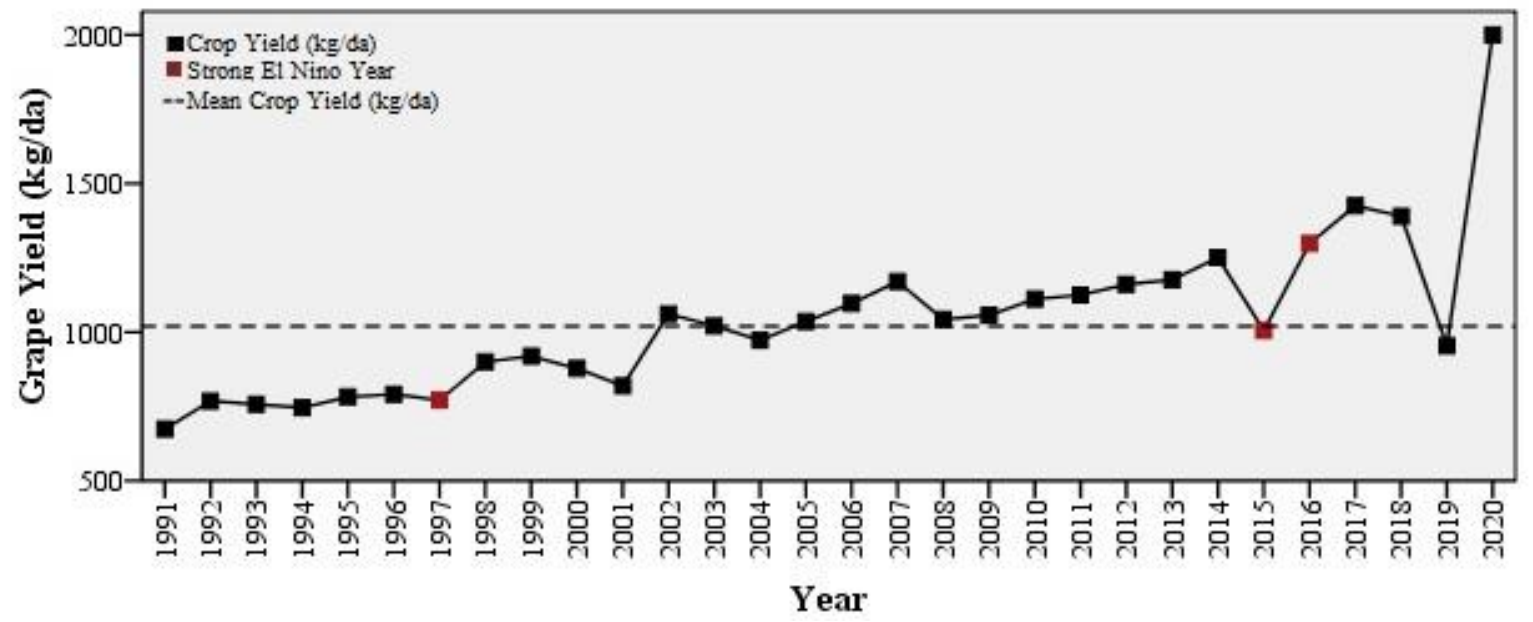

Fig. 11. Phenological year of Grape Yield in Mersin.

\section{Conclusion}

The increase in the frequency of extreme weather events (extreme temperatures, heat waves, extreme rainfall, floods, hail, etc.) that have occurred frequently in recent years are related to the large-scale pressure and changes in wind circulation and atmospheric oscillations. In studies about the climate of Turkey, it has been determined that since the 1990 s, there is a trend in some extreme values, significantly the increase of daily lowest and highest temperatures, decrease in snowy and frost days, and increase in the number of hot days and nights. Model studies on climate change also predict that the global climate will likely be more variable in many regions of the world in the future. According to the statement made by the World Meteorological Organization (WMO), the highest temperatures have been in the last five years from the date the recorded data began (1880-2020). As a result, it increases the likelihood of a climate in Turkey and its surroundings that is in a trend of deviating more frequently than the average of the long years and in which extreme climatic events will be experienced more frequently (heavy rainfall, flood, storm, tornado event, heatwave, drought, etc.). According to the results obtained from this study, while crops that adapt to tropical conditions such as cotton and grapes have a high tolerance to extreme temperatures, they are affected by intense precipitation. Olive, the bioindicator type of the Mediterranean Basin, is affected by the constantly ongoing average high temperatures and cannot complete its development as it feels the need for chilling. In addition, low precipitation during fruit formation causes low-quality fruit formation. Hence, extreme weather conditions affect the yield of these crops with high economic value in the Mediterranean Basin.

In the research period, extreme climatic conditions occurred, especially in the strong El Nino years, and directly affected the yield in the phenological stages of the crops. It seriously affects the countries whose economic activity is based on agriculture in the Mediterranean Basin, and it is likely to affect in the future. Extreme climatic conditions directly affect agricultural yield in years when the oscillations are strong. In order to prevent the occurrence of a food crisis and prevent fluctuations in food prices, possible NAO and ENSO oscillations, which are determinants of weather and climate conditions, and the effects of these oscillations on physical and human geography should be taken into account.

\section{Acknowledgements}

This study is supported by The Scientific and Technological Research Council of Turkey (TUBITAK) with Project Number 119Y041. The authors would like to thank TUBITAK for its research support at Sakarya University, Turkish State Meteorological Service (TSMS) for the supply of long-term monthly mean climatic variables and editor and reviewers for their constructive comments and useful recommendations that helped improve the quality of the paper.

\section{References}

Abahous, H., Bouchaou, L., Chehbouni, A. (2021). Global Climate Pattern Impacts on Long-Term Olive Yields in Northwestern Africa: Case from SoussMassa Region. Sustainability, 13(3), 1340.

Abd-Elmabod, S. K., Muñoz-Rojas, M., Jordán, A., Anaya-Romero, M., Phillips, J. D., Jones, L., Zhang, Z., Pereira, P., Fleskens, 1., van der Ploeg, M., de la Rosa, D. (2020). Climate change impacts on agricultural suitability and yield reduction in a Mediterranean region. Geoderma, 374, 114453.

Abdolrahimi, M. (2016). The effect of El Niño Southern Oscillation (ENSO) on world cereal production. University of Sydney.

Al-Zuhairi, M. F., Kadhum, J. H., Farhan, A. J. (2013). Time series analysis of Southern Oscillation index and temperature over Iraq. Diyala J. Pure Sci, 9, 5768.

Andrade, C., Santos, J. A., Pinto, J. G., Corte-Real, J. (2011). Large-scale atmospheric dynamics of the wet winter 2009-2010 and its impact on hydrology in Portugal. Climate Research, 46(1), 29-41.

Atalay, İ., Mortan, K. (2011). Türkiye Bölgesel Coğrafyast. İnkılap Kitabevi. 
Bachmann, N. (2007). The North Atlantic Oscillation (NAO). Termpaper writing for MSc Biogeochemistry and pollutant dynamics, ETH Zurich.

Baltac1, H., Akkoyunlu, B. O., Tayanc, M. (2018). Relationships between teleconnection patterns and Turkish climatic extremes. Theoretical and applied climatology, 134(3), 1365-1386.

Bannayan, M., Lotfabadi, S. S., Sanjani, S., Mohamadian, A., Aghaalikhani, M. (2011). Effects of precipitation and temperature on crop production variability in northeast Iran. International journal of Biometeorology, 55(3), 387-401.

Baylan, K. A., Ustaoğlu, B. (2020). Emberger biyoiklim sınıflandırmasına göre Türkiye'de Akdeniz biyoiklim katlarının ve alt tiplerinin dağılışı. Ulusal Çevre Bilimleri Araştırma Dergisi, 3(3), 158-174.

Bertrand, A., Lengaigne, M., Takahashi, K., Avadí, A., Poulain, F., \& Harrod, C. (2020). El Niño Southern Oscillation (ENSO) effects on fisheries and aquaculture. FAO Fisheries and Aquaculture Technical Paper No. 660. Rome, FAO.

Brönnimann, S., Xoplaki, E., Casty, C., Pauling, A., Luterbacher, J. (2007). ENSO influence on Europe during the last centuries. Climate Dynamics, 28(2-3), 181-197.

Capa-Morocho, M., Rodríguez-Fonseca, B., RuizRamos, M. (2014). Crop yield as a bioclimatic index of El Niño impact in Europe: Crop forecast implications. Agricultural and forest meteorology, $198,42-52$

Climate Data Guide (2018). Nino 1+2,3,3.4,4; ONI and TNI. Retrieved 28 November 2018 from https://climatedataguide.ucar.edu/climate-data/ninosst-indices-nino-12-3-34-4-oni-and-tni

Dabanl, İ., Mishra, A. K., Şen, Z. (2017). Long-term spatio-temporal drought variability in Turkey. Journal of Hydrology, 552, 779-792.

del Pozo, A., Brunel-Saldias, N., Engler, A., OrtegaFarias, S., Acevedo-Opazo, C., Lobos, G. A., JaraRojas, R., Molina-Montenegro, M. A. (2019). Climate change impacts and adaptation strategies of agriculture in Mediterranean-Climate Regions (MCRs). Sustainability, 11(10), 2769.

Doğanay, H., Coşkun, O. (2012). Tarım coğrafyası (2. bs). Pegem Akademi.

Efe, B., Lupo, A. R., Deniz, A. (2019). The relationship between atmospheric blocking and precipitation changes in Turkey between 1977 and 2016. Theoretical and Applied Climatology, 138(3), 15731590.

Efe, R., Soykan, A., Sönmez, S., Cüberal, İ. (2009). Sicaklık Şartlarının Türkiye'de Zeytinin (Olea europaea subsp. Europaea) Yetişmesine, Fenolojik ve Pomolojik Özelliklerine Etki. Ekoloji, 18(70), 17-26.

Efe, R., Soykan, A., Cüberal, İ., Sönmez, S. (2013). Dünyada, Türkiye'de, Edremit Körfezi Çevresinde Zeytin ve Zeytinyağı. Balıkesir: Edremit Belediyesi Kültür Yayınları

Fraisse, C. W., Cabrera, V. E., Breuer, N. E., Baez, J., Quispe, J., Matos, E. (2008). El Niño-Southern oscillation influences on soybean yields in Eastern Paraguay. International Journal of Climatology: A
Journal of the Royal Meteorological Society, 28(10), 1399-1407.

Gazioğlu, C. (2018). Biodiversity, coastal protection, promotion and applicability investigation of the ocean health index for Turkish seas. International Journal of Environment and Geoinformatics, 5(3), 353-367.

Gimeno, L., Ribera, P., Iglesias, R., de la Torre, L., García, R., Hernández, E. (2002). Identification of empirical relationships between indices of ENSO and NAO and agricultural yields in Spain. Climate research, 21(2), 165-172.

Golden Gate Weather Services (2021).El Niño and La Niña Years and Intensities. Retrieved 1 June 2021 from https://ggweather.com/enso/oni.htm

Gorji, T., Yildirim, A., Sertel, E., Tanik, A. (2019). Remote sensing approaches and mapping methods for monitoring soil salinity under different climate regimes. International Journal of Environment and Geoinformatics, 6(1), 33-49.

Gutierrez, L. (2017). Impacts of El Niño-Southern Oscillation on the wheat market: A global dynamic analysis. PloS one, 12(6), e0179086.

Güzey Diker, E., Yıldırım, İ., Önöz, B. (2018). Kuzey Atlantik ve Güney Salınımlarının 2007-2008 kuraklığına etkileri. Dicle University Journal of Engineering, 9(1), 53.

Hasanean, H. (2004). Precipitation variability over the Mediterranean and its linkage with El Nino Southern Oscillation (ENSO). J. Meteorol, 29(289), 151-160.

Hatzaki, M., Flocas, H. A., Giannakopoulos, C., Maheras, P. (2009). The impact of the eastern Mediterranean teleconnection pattern on the Mediterranean climate. Journal of Climate, 22(4), 977-992.

Iglesias, A., Mougou, R., Moneo, M., Quiroga, S. (2011). Towards adaptation of agriculture to climate change in the Mediterranean. Regional Environmental Change, 11(1), 159-166.

Iizumi, T., Luo, J.-J., Challinor, A. J., Sakurai, G., Yokozawa, M., Sakuma, H., Brown, M. E., Yamagata, T. (2014). Impacts of El Niño Southern Oscillation on the global yields of major crops. Nature communications, 5(1), 1-7.

IPCC, 2021 Climate Change 2021 The Physical Science Basis Working Group I Contribution to the Sixth Assessment Report of the Intergovernmental Panel on Climate Change.

Kadığlu, M., Tulunay, Y., Borhan, Y. (1999). Variability of Turkish precipitation compared to El Nino events. Geophysical Research Letters, 26(11), $1597-1600$.

Kara, H. (1988). Türkiye'de Pamuk Üretim Alanları. Coğrafya Araştırmaları Dergisi, (11), 71-90

Karabăg, S., Şahin, S., (2020). Türkiye Beşeri ve Ekonomik Coğrafyası. Pegem Akademi.

Karabörk M. Ç., Kahya, E. (2003). The teleconnections between the extreme phases of the southern oscillation and precipitation patterns over Turkey. International Journal of Climatology: A Journal of the Royal Meteorological Society, 23(13), 16071625. 
Karabörk, M. Ç., Kahya, E., Karaca, M. (2005). The influences of the Southern and North Atlantic Oscillations on climatic surface variables in Turkey. Hydrological Processes: An International Journal, 19(6), 1185-1211.

Karaca, M., Deniz, A., Tayanç, M. (2000). Cyclone track variability over Turkey in association with regional climate. International Journal of Climatology: A Journal of the Royal Meteorological Society, 20(10), 1225-1236.

Kaymaz, B. (2005). Geyve'nin iklimi ve iklim koşullarının tarımsal faaliyetlere etkisi [Yüksek Lisans Tezi]. Sakarya Üniversitesi.

King, M. P., Yu, E., Sillmann, J. (2020). Impact of strong and extreme El Niños on European hydroclimate. Tellus A: Dynamic Meteorology and Oceanography, 72(1), 1-10.

Lobell, D. B. (2014). Climate change adaptation in crop production: Beware of illusions. Global Food Security, 3(2), 72-76.

Malhi, G. S., Kaur, M., Kaushik, P. (2021). Impact of climate change on agriculture and its mitigation strategies: A review. Sustainability, 13(3), 1318.

Martı, A. İ. (2007). Türkiye'deki akım, yağış ve sicaklık verilerinin güneyli salınımla olan ilişkilerinin incelenmesi. Selçuk Üniversitesi Fen Bilimleri Enstitüsü.

Mart1, A. İ. (2014). ENSO Effect on Black Sea Precipitation. Procedia-Social and Behavioral Sciences, 140, 274-281.

Mart1, A. İ., Kahya, E. (2007). ENSO effects on mean temperature in Turkey, doi.org/10.25675/10217/ 200681

MGM, 2021, Meteorological data 1970-2020, Ankara.

Ministry of Customs and Trade, General Directorate of Cooperatives (2018a). 2017 Y1l Zeytin ve Zeytinyağı Raporu.

Ministry of Customs and Trade, General Directorate of Cooperatives (2018b). 2017 Y1lı Pamuk Raporu.

Ministry of Customs and Trade, General Directorate of Cooperatives (2018c). 2017 Yilı Cekirdeksiz Kuru Üzüm Raporu.

Nazemosadat, M., Cordery, I. (2000). On the relationships between ENSO and autumn rainfall in Iran. International Journal of Climatology: A Journal of the Royal Meteorological Society, 20(1), 47-61.

NOAA (2021a). El Nino Index Dashboard: NOAA Physical Sciences Laboratory. Retrieved 17 February 2021 from https://psl.noaa.gov/enso/dashboard.html

NOAA (2021b). Cold \& Warm Episodes by Season.

Phenology Atlas of Turkey (2001). Turkish State Meteorological Service, Ankara.

Phenology Atlas of Turkey (2014). Turkish State Meteorological Service.

PozoVázquez, D., GámizFortis, S., TovarPescador, J., EstebanParra, M., CastroDíez, Y. (2005). El NiñoSouthern Oscillation events and associated European winter precipitation anomalies. International Journal of Climatology: A Journal of the Royal Meteorological Society, 25(1), 17-31.

Price, C., Stone, L., Huppert, A., Rajagopalan, B., Alpert, P. (1998). A possible link between El Nino and precipitation in Israel. Geophysical Research Letters, 25(21), 3963-3966.

Qian, Y., Zhao, J., Zheng, S., Cao, Y., Xue, L. (2020). Risk assessment of the global crop loss in ENSO events. Physics and Chemistry of the Earth, Parts $A / B / C, 116,102845$.

Ortiz-Bobea, A., Ault, T. R., Carrillo, C. M., Chambers, R. G., Lobell, D. B. (2021). Anthropogenic climate change has slowed global agricultural productivity growth. Nature Climate Change, 11(4), 306-312.

Rao, V., Subba Rao, A., Bapuji Rao, B., Ramana Rao, B., Sravani, C., Venkateswarlu, B. (2011). El Niño effect on climatic variability and crop production: A case study for Andhra Pradesh. research Bulletin, 2.

Rasmusson, E. M., Wallace, J. M. (1983). Meteorological aspects of the El Nino/southern oscillation. Science, 222(4629), 1195-1202.

Rojas, O., Piersante, A., Cumani, M., Li, Y. (2019). Understanding the Drought Impact of El Niño/La Niña in the Grain Production Areas in Eastern Europe and Central Asia (Sy 9251313423). The World Bank.

Salameh, A. A., GámizFortis, S. R., CastroDíez, Y., Abu Hammad, A., EstebanParra, M. J. (2019). Spatiotemporal analysis for extreme temperature indices over the Levant region. International Journal of Climatology, 39(15), 5556-5582.

Samba, G., Nganga, D. (2012). Rainfall variability in CongoBrazzaville: 1932-2007. International Journal of Climatology, 32(6), 854-873.

Shabbar, A. (2006). The impact of El Niño-southern oscillation on the Canadian climate. Advances in Geosciences, 6, 149-153.

Sneyers, R. (1990). On the Statistical Analysis of Series of Observations. World Meteorological Organization.

Soler, C. M. T., Sentelhas, P. C., Hoogenboom, G. (2010). The impact of El Niño Southern Oscillation phases on offseason maize yield for a subtropical region of Brazil. International Journal of Climatology: A Journal of the Royal Meteorological Society, 30(7), 1056-1066.

Stone, D., Auffhammer, M., Carey, M., Hansen, G., Huggel, C., Cramer, W., Lobell, D., Molau, U., Solow, A., Tibig, L., Yohe, G. (2013). The challenge to detect and attribute effects of climate change on human and natural systems. Climatic Change, 121(2), 381-395.

Subash, N., Gangwar, B. (2014). Statistical analysis of Indian rainfall and rice productivity anomalies over the last decades. International journal of climatology, 34(7), 2378-2392.

TC Ministry of Agriculture and Forestry, General Directorate of Meteorology(2021). Türkiye 2020 Y1lı İklim Değerlendirmesi.

Temuçin, E. (1993). Türkiye'de Zeytin Yetişen Alanların S1caklık Değişkenine Göre İncelenmesi. Ege Coğrafya Dergisi, 7(1), 117-131.

Tosunoglu, F., Can, I., Kahya, E. (2018). Evaluation of spatial and temporal relationships between largescale atmospheric oscillations and meteorological drought indexes in Turkey. International Journal of Climatology, 38(12), 4579-4596.

TUIK (2017).Bitkisel Üretim İstatistikleri. 
TUIK (2021).. Bitkisel Üretim İstatistikleri.

Türkeş, M. (1998). Influence of geopotential heights, cyclone frequency and southern oscillation on rainfall variations in Turkey. International Journal of Climatology: A Journal of the Royal Meteorological Society, 18(6), 649-680.

Türkeş, M. (2000). El Nino-güneyli salınım ekstremleri ve Türkiye'deki yağış anomalileri ile ilişkileri. Çevre, Bilim ve Teknoloji, 1(1), 1-13.

Türkeş, M., Erlat, E. (2003). Precipitation changes and variability in Turkey linked to the North Atlantic Oscillation during the period 1930-2000. International Journal of Climatology: A Journal of the Royal Meteorological Society, 23(14), 17711796.

URL 1 (2021). Retrieved 10 March 2021 from http://www.fao.org/faostat/en/\#data/QC

Ustaoğlu, B. (2009). Türkiye'de İklim Değişikliğinin Fındık Tarımına Olası Etkileri. İTÜ/Avrasya Yer Bilimleri Enstitüsü. Doktora Tezi.

Ustaoğlu, B. (2013, July 15). Trend Analysis of Annual Mean Temperature Data Using Mann-Kendall Rank Correlation Test in Catalca - Kocaelı Penınsula, Northwest of Turkey for the Period Of 1970-2011. International Balkan Annual Conference; Second International Balkan Annual Conference.

Ustaoğlu, B. (2018). Sakarya'nın iklim özellikleri. Sakarya'nın Fiziki, Beşeri ve İktisadi Coğrafya Özellikleri, Editör: İkiel, C., Sakarya Üniversitesi Yayınları, 190.

Ustaoğlu, B., Karaca, M. (2014). The effects of climate change on spatiotemporal changes of hazelnut (Corylus avellana) cultivation areas in the Black Sea region, Turkey. Applied Ecology and Environmental Research (AEER), 12(2), 309-324.

Ustaoğlu, B., İkiel, C., Atalay Dutucu, A., \& Koç, D. E. (2021). Erosion Susceptibility Analysis in Datça and Bozburun Peninsulas, Turkey. Iranian Journal of Science and Technology, Transactions A: Science, 45(2), 557-570, doi.org/10.1007/s40995-020-010535

Ustaoğlu, B., İkiel, C. (2007). Gevye'nin İklimi ve İklim Koşullarının Tarımsal Faaliyetlere Etkisi. Akademik Incelemeler Dergisi, 2(2), 209-229.

Uzun, A., Ustaoğlu, B. (2019). Impacts of El Nino Southern Oscillation (ENSO) and North Atlantic Oscillation (NAO) on the olive yield in the mediterranean region, Turkey. 1-6.

UZZK (2020). 2020-2021 Üretim Sezonu Sofralık Zeytin Ve Zeytinyağı Rekoltesi Ulusal Resmi Tespit Heyeti Raporu.

Ülker, D., Ergüven, O., Gazioğlu, C. (2018). Socioeconomic impacts in a Changing Climate: Case Study Syria. International Journal of Environment and Geoinformatics, 5(1), 84-93.

Valdez-Cepeda, R. D., Galván-Tejada, C. E., GalvánTejada, J. I., Medina-García, G., Blanco-Macías, F., Méndez-Gallegos, S. de J., Magallanes-Quintanar, R. (2020). Relationship between precipitation anomalies and multivariate ENSO index through wavelet coherence analysis. Atmósfera, 33(3), 285-299.

VicenteSerrano, S. M. (2005). El Niño and La Niña influence on droughts at different timescales in the
Iberian Peninsula. Water Resources Research, 41(12).

Yue, S., Pilon, P., Cavadias, G. (2002). Power of the Mann-Kendall and Spearman's rho tests for detecting monotonic trends in hydrological series. Journal of hydrology, 259(1-4), 254-271.

Zengin, M. Özbahçe, A. (2014). Bitkilerin İklim ve Toprak Istekleri. Atlas Akademi.

Zubair, L. (2002). El Nino-southern oscillation influences on rice production in Sri Lanka. International Journal of Climatology, 22(2), 249260. 